\title{
Impact of deep convection and dehydration on bromine loading in the upper troposphere and lower stratosphere
}

\author{
J. Aschmann ${ }^{1}$, B.-M. Sinnhuber ${ }^{1, *}$, M. P. Chipperfield ${ }^{2}$, and R. Hossaini ${ }^{2}$ \\ ${ }^{1}$ Institute of Environmental Physics, University of Bremen, Bremen, Germany \\ ${ }^{2}$ School of Earth and Environment, University of Leeds, Leeds, UK \\ * now at: Institute for Meteorology and Climate Research, Karlsruhe Institute of Technology, Karlsruhe, Germany
}

Received: 22 October 2010 - Published in Atmos. Chem. Phys. Discuss.: 5 January 2011

Revised: 14 March 2011 - Accepted: 17 March 2011 - Published: 22 March 2011

\begin{abstract}
Stratospheric bromine loading due to very shortlived substances is investigated with a three-dimensional chemical transport model over a period of 21 years using meteorological input data from the European Centre for Medium-Range Weather Forecasts ERA-Interim reanalysis from 1989 to the end of 2009. Within this framework we analyze the impact of dehydration and deep convection on the amount of stratospheric bromine using an idealized and a detailed full chemistry approach. We model the two most important brominated short-lived substances, bromoform $\left(\mathrm{CHBr}_{3}\right)$ and dibromomethane $\left(\mathrm{CH}_{2} \mathrm{Br}_{2}\right)$, assuming a uniform convective detrainment mixing ratio of 1 part per trillion by volume (pptv) for both species. The contribution of very short-lived substances to stratospheric bromine varies drastically with the applied dehydration mechanism and the associated scavenging of soluble species ranging from $3.4 \mathrm{pptv}$ in the idealized setup up to $5 \mathrm{pptv}$ using the full chemistry scheme. In the latter case virtually the entire amount of bromine originating from very short-lived source gases is able to reach the stratosphere thus rendering the impact of dehydration and scavenging on inorganic bromine in the tropopause insignificant. Furthermore, our long-term calculations show that the mixing ratios of very short-lived substances are strongly correlated to convective activity, i.e. intensified convection leads to higher amounts of very shortlived substances in the upper troposphere/lower stratosphere especially under extreme conditions like El Niño seasons. However, this does not apply to the inorganic brominated product gases whose concentrations are anti-correlated to convective activity mainly due to convective dilution and possible scavenging, depending on the applied approach.
\end{abstract}

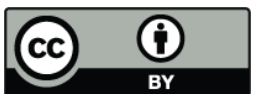

Correspondence to: J. Aschmann (jan.aschmann@iup.physik.uni-bremen.de)

\section{Introduction}

It is generally accepted that very short-lived substances (VSLS) contribute significantly to stratospheric bromine loading and ozone depletion in addition to the long-lived halons and methyl bromide (e.g., Montzka and Reimann, 2010). However, there are still significant uncertainties how and to what extent VSLS are transported into the upper troposphere/lower stratosphere (UTLS) and the response of this to possible changes under future atmospheric conditions.

Recent studies deduced the contribution of VSLS to stratospheric inorganic bromine $\left(\mathrm{Br}_{\mathrm{y}}\right)$ via observations of $\mathrm{BrO}$ ranging from $\sim 3$ pptv (Sinnhuber et al., 2005) over $\sim 5$ pptv (McLinden et al., 2010) up to $\sim 8.4 \mathrm{pptv}$ (Sioris et al., 2006) for satellite measurements and $\sim 5.2 \mathrm{pptv}$ using a balloon-borne instrument (Dorf et al., 2008). Modeling studies to evaluate the contribution of brominated VSLS also give a wide range of estimates reaching from $0.8-3$ pptv (Dvortsov et al., 1999; Nielsen and Douglass, 2001; Sinnhuber and Folkins, 2006; Kerkweg et al., 2008; Gettelman et al., 2009; Aschmann et al., 2009; Hossaini et al., 2010) to 4.85 pptv (Schofield et al., 2011; Liang et al., 2010) and 6-7 pptv (Warwick et al., 2006), although the differences in the underlying approaches and assumptions between each study make a direct comparison difficult. Commonly included VSLS are bromoform $\left(\mathrm{CHBr}_{3}\right)$ and dibromomethane $\left(\mathrm{CH}_{2} \mathrm{Br}_{2}\right)$ which are according to Montzka and Reimann (2010) the most abundant very short-lived bromocarbons with an average mixing ratio in the marine boundary layer of 1.6 and $1.1 \mathrm{pptv}$, respectively. Being mainly of natural origin from maritime lifeforms, local mixing ratios can be much higher in coastal or upwelling areas (e.g., Carpenter and Liss, 2000; Quack and Wallace, 2003; Yokouchi et al., 2005; Butler et al., 2007) thus introducing a significant uncertainty in the actual source strength.

Published by Copernicus Publications on behalf of the European Geosciences Union. 
Furthermore, the transport and dehydration mechanisms in the tropical tropopause are not fully understood. Deep convection is thought to be the most important pathway into the stratosphere by enabling air parcels to overcome the level of zero clear sky radiative heating (e.g., Corti et al., 2005; Sinnhuber and Folkins, 2006; Fueglistaler et al., 2009). During this ascent air gets effectively dehydrated and thus soluble species are likely to be scavenged by falling water/ice particles. However, important details of the dehydration process remain unclear and are still subject to current discussions (e.g., Sherwood and Dessler, 2001; Holton and Gettelman, 2001; Fueglistaler et al., 2005, 2009). Moreover, dissolved or adsorbed halogenated species may undergo heterogeneous reactions which are able to release active radicals into the gas phase (e.g., Montzka and Reimann, 2010). Since a significant part of $\mathrm{Br}_{\mathrm{y}}$ at the base of the tropical tropopause layer (TTL) is actually $\mathrm{HBr}$ and therefore highly soluble (e.g., Lary, 1996; Sinnhuber et al., 2002; Yang et al., 2005, see also Fig. 4), the estimation of VSLS contribution to stratospheric bromine loading is highly sensitive to the implementation of these processes in a model. Note that due to the general absence of liquid water in the UTLS the terms "washout" and "scavenging" will be used in the following to refer to the uptake and loss of trace gases on falling ice particles rather on droplets, unless stated otherwise.

For this study we use a three-dimensional (3-D) chemistry transport model (CTM) to investigate the impact of VSLS on stratospheric bromine loading over a 21 -year period. The isentropic model contains an explicit treatment of convection separated from the large-scale vertical transport which allows a realistic distribution of VSLS in the UTLS region (Aschmann et al., 2009). For the chemistry and dehydration implementation we used a twofold approach: On the one hand we have a simplified setup based on idealized tracers and processes acting as a sensitivity study. On the other hand we use a complex chemistry scheme with detailed treatment of gas phase and heterogeneous reactions, photochemistry and sedimentation to assure a more realistic representation of the involved processes.

\section{Model description}

\subsection{Three-dimensional chemical transport model}

The model used in this study is an isentropic 3-D CTM with 29 levels between 330 and $2700 \mathrm{~K}$ (about 10 to $55 \mathrm{~km}$ ) and a spatial resolution of $2.5^{\circ}$ lat. $\times 3.75^{\circ}$ lon. which was already utilized in our previous work (for details see Aschmann et al., 2009). It is driven by meteorological input data from ERA-Interim (EI) reanalysis of the European Centre for Medium-Range Weather Forecasts (ECMWF). A distinctive feature of our isentropic CTM is the separation of vertical transport into a slow large-scale heating-rate-driven component on the one hand and fast localized convective up- drafts on the other hand which allows a more realistic representation of troposphere to stratosphere exchange. The convective transport is based on archived detrainment rates taken from the EI reanalysis.

For the tracer and chemistry configuration we use two approaches, an idealized setup based on simple assumptions and a complex setup including a more complete chemistry scheme, these are described in detail in the following sections.

All runs were executed from 1989 to 2009 spanning almost the entire available EI dataset with a model timestep of $15 \mathrm{~min}$. However, we found that in order to use as much as possible of the 21-year time period for our purpose we needed a realistic initial configuration. A recent similar study conducted by Liang et al. (2010) shows that their model (GEOS CCM Version 2) needs a spin-up time of 13 years to reach steady state for the zero-initialized brominated product gases. Our model needs significantly longer to reach equilibrium (about 20 years) in a comparable setup. The mean age of air as indicator for the circulation speed in our model agrees generally well with results from $\mathrm{SF}_{6}$ observations (Stiller et al., 2008) but tends to be indeed up to two years older in higher altitudes/latitudes which may lead to the longer spin-up time. To reduce the impact of initialization artifacts on our study we therefore used the output of previous long-term runs as initial configuration.

\subsection{Idealized setup}

The simplified approach presented here is an expanded version of the setup described in Aschmann et al. (2009): two idealized tracers with a lifetime of 20 and 120 days (TT20, TT120) resemble the most important short-lived brominated source gases $\mathrm{CHBr}_{3}$ and $\mathrm{CH}_{2} \mathrm{Br}_{2}$, respectively (Montzka and Reimann, 2010). Convective upwelling is the only source for TT20/TT120 which detrain with a uniform detrainment mixing ratio $\left([\mathrm{TT} 20]_{\mathrm{c}},[\mathrm{TT} 120]_{\mathrm{c}}\right)$ of $1 \mathrm{pptv}$ each. These values are lower than the recommended mixing ratios in the marine boundary layer (1.6 and $1.1 \mathrm{pptv}$ for $\mathrm{CHBr}_{3}$ and $\mathrm{CH}_{2} \mathrm{Br}_{2}$, respectively, Montzka and Reimann, 2010), taking into account dilution by entrainment of free tropospheric air, which may have significant impact on deep convective plumes (e.g., Romps and Kuang, 2010). Tropospheric profiles of these species obtained from a compilation of aircraft measurements (Liang et al., 2010) suggest that a detrainment mixing ratio of $1 \mathrm{pptv}$ for bromoform and dibromomethane is a valid approximation.

The brominated source gases eventually decay into inorganic bromine $\left(\mathrm{Br}_{\mathrm{y}}\right)$, yielding three and two units of $\mathrm{Br}_{\mathrm{y}}$ for one unit of TT20 and TT120, respectively. Water vapor content is controlled by convection (detraining air is assumed to be fully saturated due to ice lofting, following Dessler and Sherwood, 2004), fallout of ice (if the relative humidity with respect to ice in a model grid box raises above $100 \%$ all surplus water is removed instantaneously) 
Table 1. Brominated species in full chemistry setup.

\begin{tabular}{ll}
\hline Category & Species \\
\hline Source gases & $\mathrm{CH}_{3} \mathrm{Br}, \mathrm{CBrClF}_{2}, \mathrm{CBrF}_{3}$, \\
& $\mathrm{CHBr}_{3}, \mathrm{CH}_{2} \mathrm{Br}_{2}$ \\
Product gases & $\mathrm{BrONO}_{2}, \mathrm{BrCl}, \mathrm{HOBr}$, \\
$\left(\mathrm{Br}_{\mathrm{y}}\right)$ & $\mathrm{HBr}, \mathrm{Br}, \mathrm{BrO}$ \\
\hline
\end{tabular}

Table 2. Heterogeneous activation reactions of dissolved/adsorbed bromine species on liquid aerosols, NAT and ice particles in the full chemistry setup. Only the uptake coefficient $\gamma$ for ice particle surfaces is given here, obtained from Sander et al. (2006).

\begin{tabular}{|c|c|c|c|}
\hline Reactants & & Products & $\gamma$ \\
\hline $\mathrm{HOBr}+\mathrm{HBr}$ & $\rightarrow$ & $2 \mathrm{Br}+\mathrm{H}_{2} \mathrm{O}$ & 0.12 \\
\hline $\mathrm{HOBr}+\mathrm{HCl}$ & $\rightarrow$ & $\mathrm{BrCl}+\mathrm{H}_{2} \mathrm{O}$ & 0.3 \\
\hline $\mathrm{HOCl}+\mathrm{HBr}$ & $\rightarrow$ & $\mathrm{BrCl}+\mathrm{H}_{2} \mathrm{O}$ & 0.06 \\
\hline $\mathrm{BrONO}_{2}+\mathrm{HBr}$ & $\rightarrow$ & $2 \mathrm{Br}+\mathrm{HNO}_{3}$ & 0.3 \\
\hline $\mathrm{BrONO}_{2}+\mathrm{H}_{2} \mathrm{O}$ & $\rightarrow$ & $\mathrm{HOBr}+\mathrm{HNO}_{3}$ & 0.3 \\
\hline $\mathrm{ClONO}_{2}+\mathrm{HBr}$ & $\rightarrow$ & $\mathrm{BrCl}+\mathrm{HNO}_{3}$ & 0.3 \\
\hline
\end{tabular}

and a simple methane oxidation parametrization (details in Aschmann et al., 2009).

Inorganic bromine is represented in two variants, soluble and insoluble, both having a constant detrainment mixing ratio of 0 pptv. Whereas the insoluble $\mathrm{Br}_{\mathrm{y}}$ is inert with no additional sinks in our model, the soluble version is subject to a simple washout mechanism: whenever ice forms in a model grid box (i.e. relative humidity exceeds $100 \%$ ) all soluble $\mathrm{Br}_{\mathrm{y}}$ is removed completely. These two extreme cases allow the estimation of an upper and lower bound of bromine loading avoiding the details of cloud and aerosol microphysics.

\subsection{Full chemistry setup}

The complex chemistry scheme used here is based originally on the chemistry part of the SLIMCAT model by Chipperfield (1999) and was updated and modified by Sinnhuber et al. (2003) and Winkler et al. (2008). It contains about 180 gas phase, heterogeneous and photochemical reactions for 59 tracers which are evaluated in every model timestep. Reaction rates and absorption cross sections utilized in the chemistry scheme correspond to the Jet Propulsion Laboratory (JPL) recommendations (Sander et al., 2006). Especially relevant for this study are the brominated species which are listed in Table 1 . The loss of the included brominated VSLS $\left(\mathrm{CHBr}_{3}\right.$ and $\left.\mathrm{CH}_{2} \mathrm{Br}_{2}\right)$ by $\mathrm{OH}-$ reaction and photolysis is modeled explicitly. However, we ignore the detailed chemistry of the degradation products and assume that the VSLS directly decay into atomic bromine, which is according to the recent study of Hossaini et al. (2010) a valid approximation.
The SLIMCAT chemistry scheme incorporates an equilibrium treatment of a set of reactions on liquid $\mathrm{H}_{2} \mathrm{O} / \mathrm{H}_{2} \mathrm{SO}_{4} / \mathrm{HNO}_{3} / \mathrm{HCl}$ aerosols, solid nitric acid trihydrate (NAT) and ice particles; the relevant reactions for bromine are listed in Table 2. The composition of liquid aerosols and the corresponding solubilities of $\mathrm{HBr}$ and $\mathrm{HOBr}$ are calculated using the analytical scheme of Carslaw et al. (1995a,b). NAT particles form according to the expression of Hanson and Mauersberger (1988) when they are thermodynamically possible. Both implementations are taken unchanged from Chipperfield (1999) and are not described in any further detail here. More relevant for this study is the uptake of halogenated species on ice particles which is, according to sensitivity calculations, the dominant process in the tropical UTLS in our model (Sect. 3.2.2) and may lead either to eventual scavenging by sedimentation or activation by heterogeneous reactions. Therefore this part of the original SLIMCAT scheme was augmented in the course of this work to improve the representation of the involved processes.

Ice is formed in a model grid box whenever the actual water mixing ratio exceeds the saturation mixing ratio of water vapor over ice, i.e. if the relative humidity is higher than $100 \%$ all excess water is in solid phase. Then we model the uptake of gaseous $\mathrm{HBr}$ on ice using the partition coefficient $K_{\text {linC }}$ for $\mathrm{HBr}\left(4.14 \times 10^{5} \mathrm{~cm}\right)$ from the recent recommendation of the IUPAC Subcommittee on Gas Kinetic Data Evaluation for Atmospheric Chemistry (Crowley et al., 2010):

$$
[\mathrm{HBr}]_{\mathrm{s}}=[\mathrm{HBr}]_{\mathrm{g}}^{0.88} \cdot K_{\mathrm{linC}} \cdot A
$$

Here $A$ denotes the surface area density which is calculated from the effective particle radius $r_{\mathrm{e}}$ and an assumed number density $n$ of 10 particles per cubic centimeter (Chipperfield, 1999):

$A=4 \pi \cdot r_{\mathrm{e}}^{2} \cdot n$

The effective particle radius $r_{\mathrm{e}}$ is approximated from the total ice volume and the total number of ice particles in a particular model box. The relation of $A$ to the fraction of adsorbed $\mathrm{HBr}$ is illustrated in Fig. 6. The heterogeneous reaction rates $k_{\mathrm{h}}$ on the particle surface are then calculated as product of uptake coefficient $\gamma$ and the collision frequency $v$ (e.g., Rodriguez et al., 1989):

$k_{\mathrm{h}}=\gamma \nu$

$v=\frac{1}{4} A \sqrt{\frac{8 k T}{\pi M}}$

with Boltzmann's constant $k$, temperature $T$ and the molecular weight $M$ of the gas molecules. Sedimentation is calculated as well but is treated simply assuming a fixed mean particle radius of $10 \mu \mathrm{m}$ for ice to determine the fall velocity (about $1.5 \mathrm{~km} \mathrm{day}^{-1}$, Böhm, 1989). As the original SLIMCAT scheme does not contain any explicit treatment of evaporation, all dissolved and adsorbed species are released back 
into gas phase instantaneously after the chemical integration step and the sedimentation calculation.

The initial tracer configuration and detrainment mixing ratios are derived from previous 2-D model runs with a similar chemistry scheme (Sinnhuber et al., 2003). The detrainment mixing ratios of the brominated VSLS are set uniformly to $1 \mathrm{pptv}$ analogous to the idealized setup. To capture the observed trend of long-lived halocarbons in our model we use time-dependent detrainment mixing ratios for these species according to the estimations of Daniel and Velders (scenario A1, 2010). Further details of the chemistry scheme, the involved reactions and processes are given in Chipperfield (1999).

\section{Results}

\subsection{Water vapor}

A realistic distribution of water vapor content in the UTLS region is crucial for our modeling approach because uptake of soluble species and scavenging relies directly on an adequate representation of dehydration. Figure 1 shows the tape recorder signature (e.g., Mote et al., 1995) of tropical water vapor mixing ratio for the idealized and full chemistry setup and for satellite observations from HALOE (Grooß and Russell, 2005). Dry phase and speed of the tape recorder signal is generally well reproduced but both modeling approaches show too much water (on average about 1 to $1.5 \mathrm{ppmv}$ ) in the UTLS region in boreal summer which is not supported by the HALOE observations. It is possible that our calculations tend to overestimate the water content of the tropical tropopause and therefore the influence of dehydration on stratospheric bromine loading. However, other measurements show indeed higher mixing ratios of water vapor in this region during boreal summer (e.g., Dessler and Sherwood, 2004; Hanisco et al., 2007; Jiang et al., 2010).

In our model, dehydration occurs mainly in the upper troposphere/tropopause region, predominantly in the tropics (Fig. 2) which is in agreement with previous studies (e.g., Gettelman et al., 2002a; Fueglistaler et al., 2005; Read et al., 2008). At high latitudes the ambient meteorological conditions allow the formation of ice even up to $25 \mathrm{~km}$ altitude, i.e. Type II polar stratospheric clouds (e.g., Solomon, 1999; Lowe and MacKenzie, 2008). Generally, the mixing ratios for ice are larger in the full chemistry setup since the idealized approach lacks a sedimentation mechanism, thus all ice is instantaneously removed from the corresponding grid box.

\subsection{Stratospheric bromine loading due to VSLS}

In general two processes control stratospheric bromine loading due to VSLS in both modeling approaches. The first one, convection, represented by the convective detrainment rate $d_{\mathrm{c}}$, injects VSLS into the UTLS region and thus enables
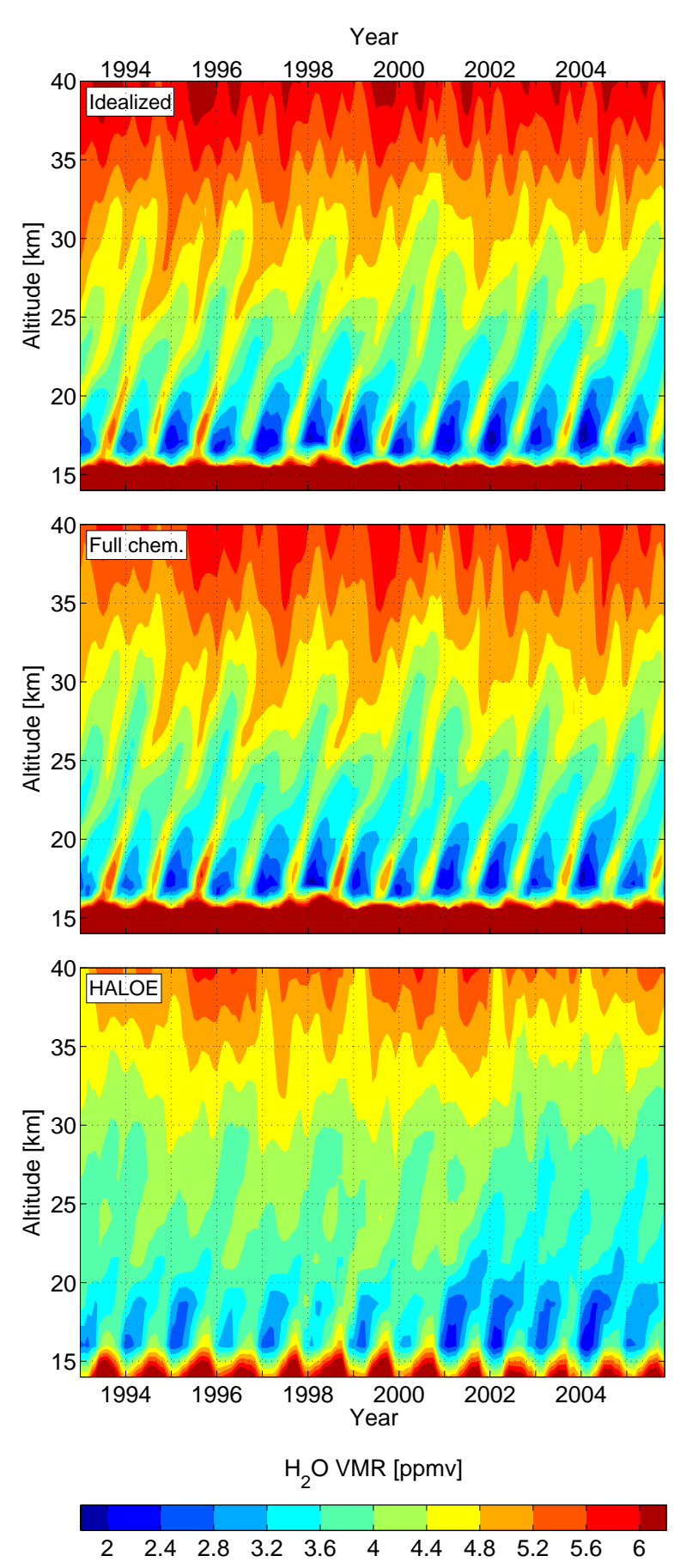

Fig. 1. Comparison of tropical $\left(20^{\circ} \mathrm{N}\right.$ to $\left.20^{\circ} \mathrm{S}\right)$ water vapor mixing ratios ("tape recorder") of idealized setup (top), full chemistry setup (middle) and HALOE observations (bottom, Grooß and Russell, 2005).

these species to contribute to stratospheric bromine abundance eventually. Therefore, the mixing ratio of $\mathrm{Br}_{\mathrm{y}}$ (or the corresponding inorganic bromine substances in the full chemistry setup, Table 1) is reduced by dilution since the detraining air is assumed to be free of $\mathrm{Br}_{\mathrm{y}}$, i.e. its detrainment 

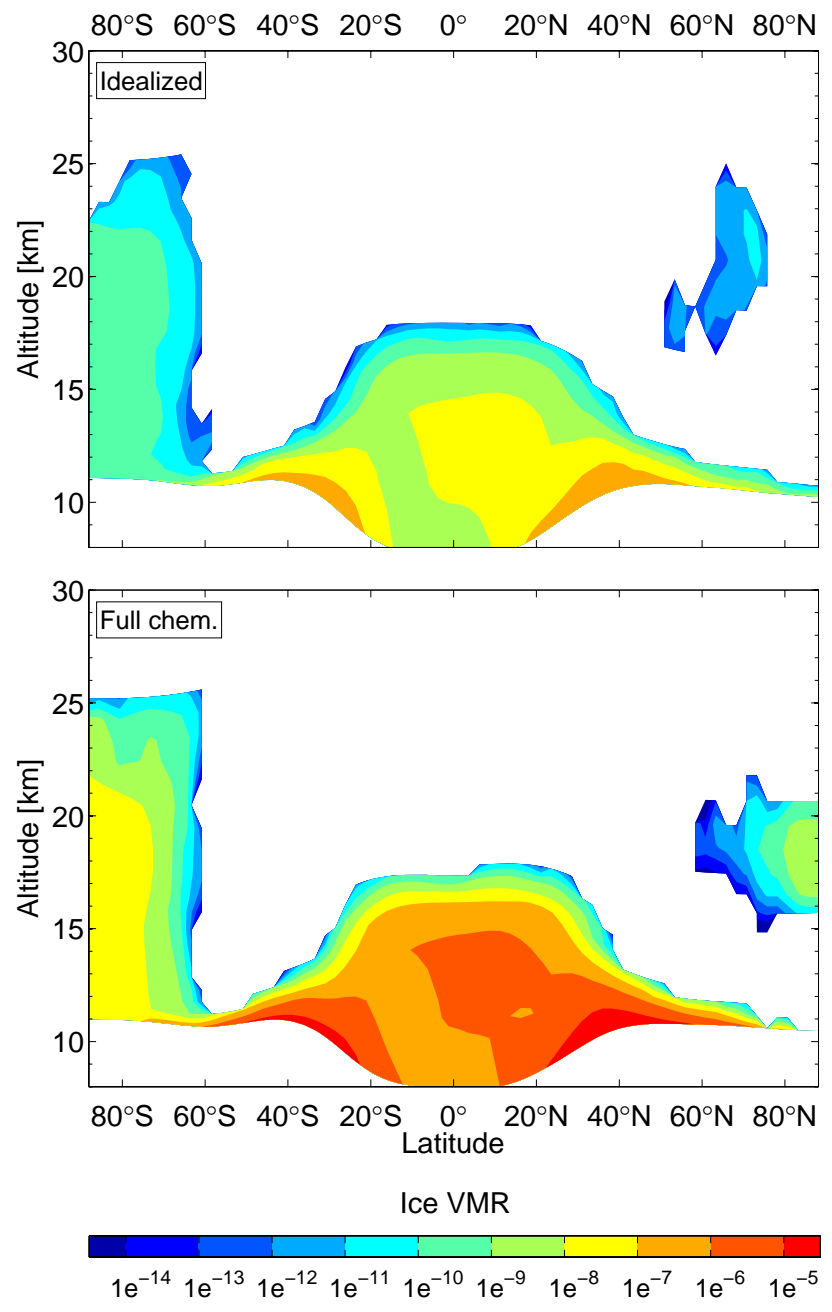

Fig. 2. Averaged equivalent gas phase volume mixing ratio of ice in idealized setup (top) and full chemistry setup (bottom) for 2006.

mixing ratio is zero. The other important mechanism is the dehydration of air at the tropopause which may cause a significant removal of soluble $\mathrm{Br}_{\mathrm{y}}$ by falling ice depending on the implementation in the model.

As first step, we illustrate the impact of these processes on the stratospheric bromine loading by comparing both modeling approaches for a single year, 2006. We picked this particular year because it is in the last quarter of our covered time period minimizing the effect of initialization artifacts. More important, 2006 is a year relatively unaffected by the El Niño Southern Oscillation (ENSO) that is typically accompanied by strong perturbations in sea surface temperature and convective activity (e.g., Ramanathan and Collins, 1991; Barsugli and Sardeshmukh, 2002; Chiang and Sobel, 2002; Guilyardi et al., 2009) that would otherwise influence our results (see Sect. 3.3).

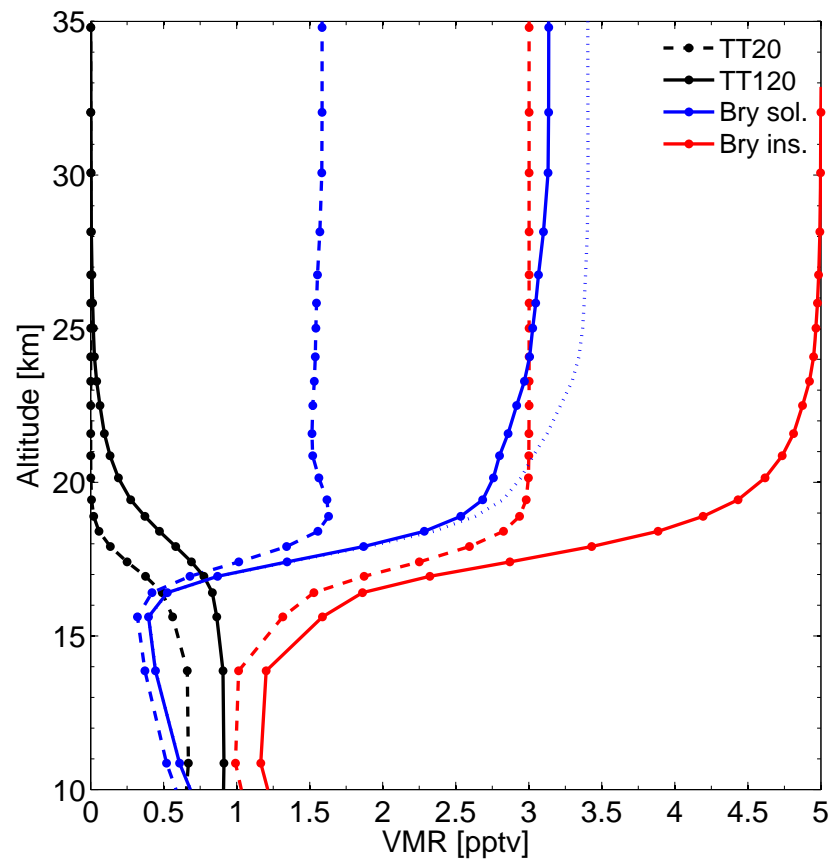

Fig. 3. Averaged tropical profiles $\left(20^{\circ} \mathrm{N}\right.$ to $\left.20^{\circ} \mathrm{S}\right)$ of TT20 $\left(\mathrm{CHBr}_{3}\right), \mathrm{TT} 120\left(\mathrm{CH}_{2} \mathrm{Br}_{2}\right)$ and soluble and insoluble $\mathrm{Br}_{\mathrm{y}}$ for 2006. The dashed profiles of soluble/insoluble $\mathrm{Br}_{\mathrm{y}}$ resulting from a setup where TT20 is the only brominated source gas (as in Aschmann et al., 2009) whereas the solid profiles denote the model run with both TT20 and TT120. The assumed detrainment mixing ratio for both VSLS is 1 pptv. The dotted blue profile marks soluble $\mathrm{Br}_{\mathrm{y}}$ from a sensitivity run where washout of $\mathrm{Br}_{\mathrm{y}}$ is restricted to within $40^{\circ} \mathrm{N}$ to $40^{\circ} \mathrm{S}$.

\subsubsection{Idealized setup}

Figure 3 shows averaged tropical $\left(20^{\circ} \mathrm{N}\right.$ to $\left.20^{\circ} \mathrm{S}\right)$ profiles for 2006 of brominated source and product gases illustrating typical distributions. The dashed profiles represent our earlier modeling study where we only incorporated TT20 $\left(\mathrm{CHBr}_{3}\right)$ as source gas (Aschmann et al., 2009). The suggested stratospheric bromine loading is in the range of 1.6 to 3 pptv assuming the detrainment mixing ratio of the only source, TT20, is $1 \mathrm{pptv}$. Taking into account that one unit of TT20 decays into three units of $\mathrm{Br}_{\mathrm{y}}$ this means that at least $50 \%$ of all bromine originating from TT20 was unaffected by washout and is able to enter the stratosphere. Introducing TT120 $\left(\mathrm{CH}_{2} \mathrm{Br}_{2}\right)$ as additional source gas with $[\mathrm{TT} 120]_{\mathrm{c}}=1 \mathrm{pptv}$ changes the previous estimation to 3.1 to 5 pptv (solid profiles). Consequently about 1.5 to $2 \mathrm{pptv}$ is originating from TT120, i.e. at least $75 \%$ of the total available TT120 is not affected by washout assuming a production rate of $1: 2$ for $\mathrm{TT} 120 / \mathrm{Br}_{\mathrm{y}}$.

Another aspect of the idealized setup that influences our results is the assumption regarding the partitioning of $\mathrm{Br}_{\mathrm{y}}$. In the idealized setup, $\mathrm{Br}_{\mathrm{y}}$ is either considered totally soluble or insoluble throughout the atmosphere. In comparison, 
Fig. 4 shows the percentage of $\mathrm{HBr}$ to the total amount of $\mathrm{Br}_{\mathrm{y}}$ for the full chemistry run. The fraction of soluble inorganic bromine is large only at the base of the tropical tropopause and diminishes rapidly with increasing altitude and latitude which is supported by earlier studies (e.g., Lary, 1996; Sinnhuber et al., 2002; Yang et al., 2005). Since we constructed the soluble $\mathrm{Br}_{\mathrm{y}}$ tracer to be affected uniformly by washout this significantly overestimates the impact of dehydration, especially near the South Pole where Type II polar stratospheric clouds play an important role (see Fig. 2). Switching off the scavenging process at higher latitudes $\left(>40^{\circ} \mathrm{N} / \mathrm{S}\right)$ increases the lower limit of the contribution of VSLS from 3.1 to $3.4 \mathrm{pptv}$ (dotted profile in Fig. 3).

\subsubsection{Full chemistry setup}

The full chemistry run incorporates long-lived brominated source gases that define a bromine background in the stratosphere. Moreover, emissions of the long-lived source gases are changing over time which makes the assessment of the impact of VSLS on stratospheric bromine loading more complicated. To identify this background we conducted a reference run which does not include brominated VSLS but is identical to the full chemistry setup otherwise.

Figure 5 shows the averaged tropical profiles of brominated source and product gases in 2006 for the full chemistry runs. The mixing ratio of the long-lived source gases $\left(\mathrm{CH}_{3} \mathrm{Br}, \mathrm{CBrClF}_{2}, \mathrm{CBrF}_{3}\right)$ at the tropopause ( $\left.14.7 \mathrm{pptv}\right)$ defines the abundance of inorganic bromine in the stratosphere ( $\sim 14.1 \mathrm{pptv}$ for the reference run) with a small discrepancy of $0.6 \mathrm{pptv}$. Significant loss of $\mathrm{Br}_{\mathrm{y}}$ due to scavenging can be ruled out since the long-lived species are primarily photolyzed above altitudes where dehydration is important (e.g., Sander et al., 2006; Hossaini et al., 2010). What causes the difference is rather the variable "emission" (to be precise: the changing detrainment mixing ratio) of the longlived brominated species. The relatively slow transport in the stratosphere compared to the troposphere introduces a time lag in the mixing ratio of $\mathrm{Br}_{\mathrm{y}}$, i.e. some parts of the stratosphere still contain older air parcels with less $\mathrm{Br}_{\mathrm{y}}$.

The full chemistry run with very short-lived source gases included shows a stratospheric abundance of $\mathrm{Br}_{\mathrm{y}}$ of $\sim 19$ pptv, i.e. $\sim 4.9$ pptv more than the reference run (Fig. 5). Considering that we added 5 pptv of additional bromine in the VSLS setup originally (detrainment mixing ratio of $\mathrm{CHBr}_{3}$ and $\mathrm{CH}_{2} \mathrm{Br}_{2}$ is 1 pptv each) this means that almost the entire amount of bromine from short-lived substances is able to reach the stratosphere. Apparently the effect of dehydration and scavenging on stratospheric bromine loading is negligible in the full chemistry setup.

This has several reasons. First, the mixing ratio of $\mathrm{HBr}$ in the transient altitude range between the level of zero radiative heating and the cold point is relatively small (about $0.15 \mathrm{pptv}$, Fig. 4), the average fraction of $\mathrm{HBr}$ to $\mathrm{Br}_{\mathrm{y}}$ below $5 \%$. Consequently, the majority of inorganic bromine at this altitude
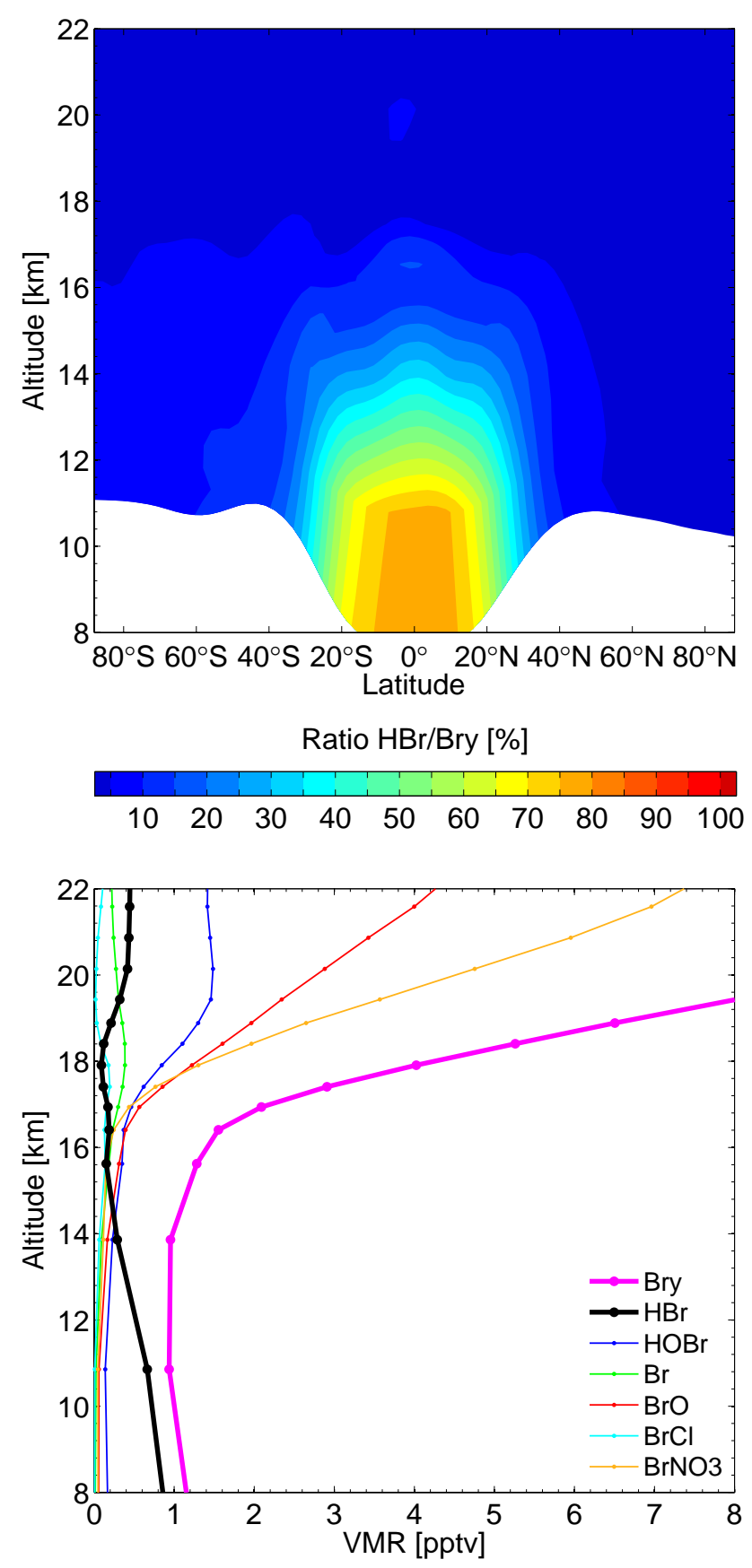

Fig. 4. Average $\mathrm{Br}_{\mathrm{y}}$ partitioning for 2006 derived from the full chemistry run. Top panel: Ratio of the soluble species $\mathrm{HBr}$ to $\mathrm{Br}_{\mathrm{y}}$. Bottom panel: Profiles of $\mathrm{Br}_{\mathrm{y}}$ constituents in the tropical UTLS.

is actually insoluble with respect to ice in our model. Note that we have assumed here that only $\mathrm{HBr}$ is adsorbed on ice. We included heterogeneous reactions for $\mathrm{HOBr}$ and $\mathrm{BrONO}_{2}$ on ice surfaces as well (Table 2), however, as it is currently not clear how and to what extent $\mathrm{HOBr}$ and $\mathrm{BrONO}_{2}$ are adsorbed on ice (Crowley et al., 2010), we do not explicitly model the uptake as we do with $\mathrm{HBr}$. The partitioning 


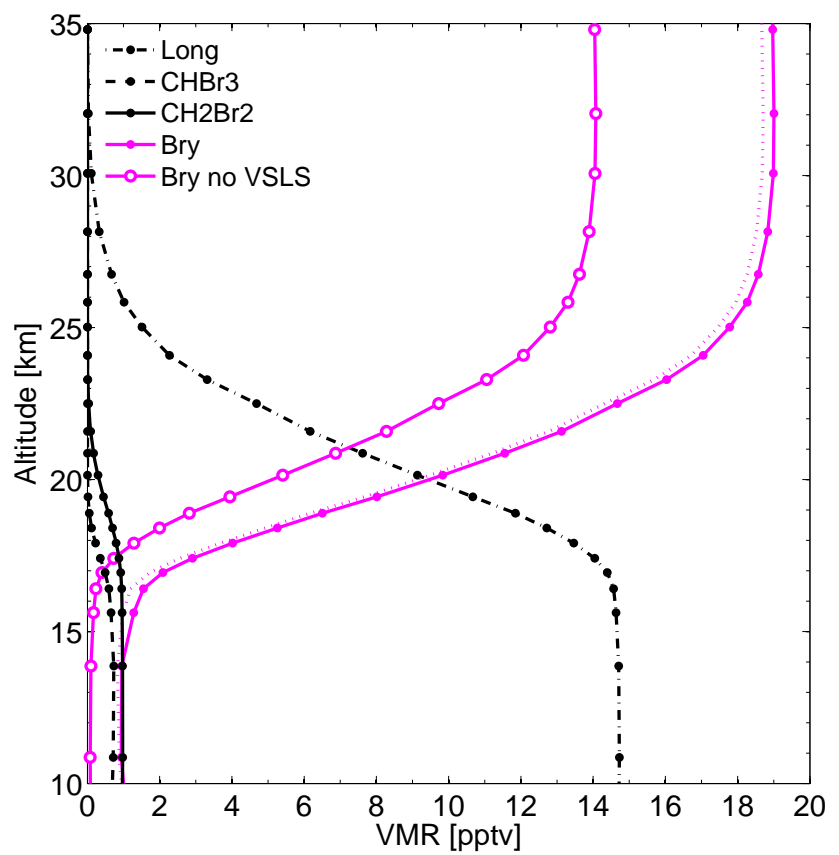

Fig. 5. Averaged tropical profiles $\left(20^{\circ} \mathrm{N}\right.$ to $\left.20^{\circ} \mathrm{S}\right)$ of long-lived brominated source gases $\left(\mathrm{CH}_{3} \mathrm{Br}, \mathrm{CBrClF}_{2}\right.$ and $\left.\mathrm{CBrF}_{3}\right)$, bromoform $\left(\mathrm{CHBr}_{3}\right)$, dibromomethane $\left(\mathrm{CH}_{2} \mathrm{Br}_{2}\right)$ and inorganic brominated product gas $\left(\mathrm{Br}_{\mathrm{y}}\right.$, see Table 1$)$ for 2006 . Both VSLS have an assumed uniform detrainment mixing ratio of 1 pptv. The $\mathrm{Br}_{\mathrm{y}}$ profile with filled and empty markers denote a model run with and without VSLS incorporated, respectively. The dotted $\mathrm{Br}_{\mathrm{y}}$ profile is derived from a sensitivity calculation where VSLS are included but the heterogeneous activation reactions (see Table 2) are switched off.

between $\mathrm{HBr}$ and $\mathrm{Br}_{\mathrm{y}}$ in the chemistry scheme is controlled mainly by the gas phase reactions in Table 3 , the heterogeneous reactions in Table 2 and the uptake and sedimentation on ice.

Furthermore, the fraction of adsorbed $\mathrm{HBr}$ on ice is relatively small as well. Figure 6 shows the relation of available ice particle surface area density and the resulting fraction of adsorbed $\mathrm{HBr}$ to total $\mathrm{HBr}$ according to Eq. (1) and the relative frequency of occurrence of surface area density values in the tropical tropopause region for 2006: in 95\% of all model grid boxes where ice forms the percentage of $\mathrm{HBr}$ on ice is significantly lower than $46 \%$ thus limiting the possible impact of scavenging directly.

In addition a major part of $\mathrm{HBr}$ on ice undergoes heterogeneous activation that releases reactive bromine back into gas phase. To investigate this effect we conducted another sensitivity run identical to the full chemistry setup with VSLS but without the heterogeneous reactions for $\mathrm{HBr}$ as listed in Table 2. Figure 7 presents tropical $\mathrm{HBr}$ profiles for both the standard and the sensitivity run. In the standard setup, the mixing ratio of $\mathrm{HBr}$ drops rapidly between 15 and $17 \mathrm{~km}$ altitude. The heterogeneous chemistry effectively depletes

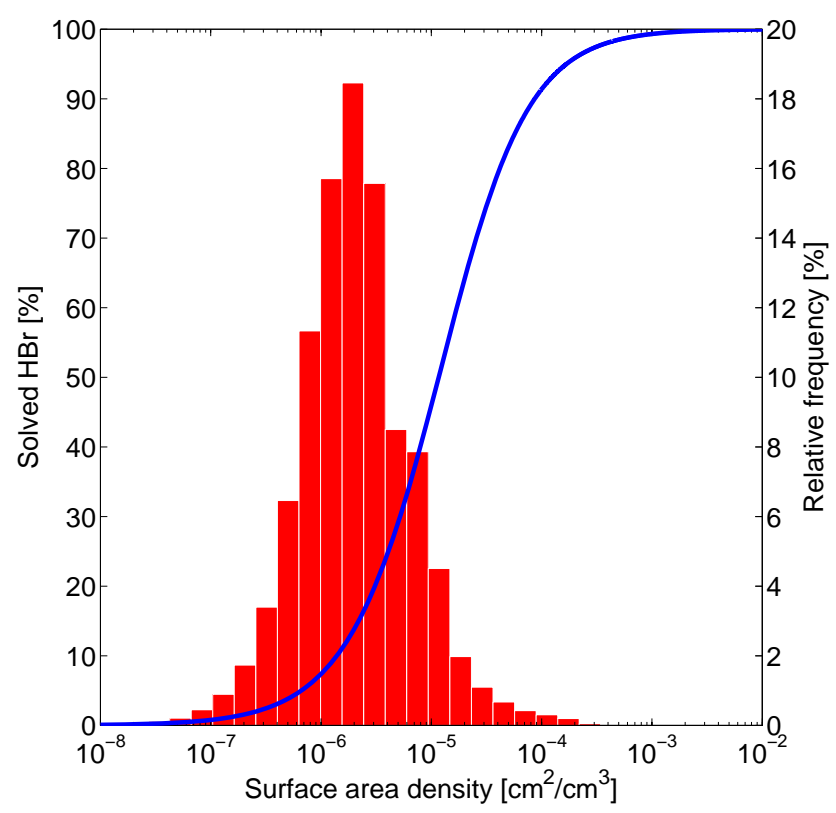

Fig. 6. Relation between available ice particle surface area density in a model box and the resulting fraction of adsorbed $\mathrm{HBr}$ on ice to total $\mathrm{HBr}$ derived from Eq. (1) (blue line, left ordinate). The red bars indicate the relative frequency of occurrence of surface area density values in the tropical tropopause $\left(20^{\circ} \mathrm{N}\right.$ to $20^{\circ} \mathrm{S}, 330 \mathrm{~K}$ to $\left.380 \mathrm{~K}\right)$ for 2006 of the full chemistry run (right ordinate). The fraction of adsorbed $\mathrm{HBr}$ is lower than $46 \%$ in $95 \%$ of all calculated surface area densities.

Table 3. Gas phase reactions in the full chemistry setup that lead to the formation/destruction of $\mathrm{HBr}$ and the corresponding rate constant $k(T)$ obtained from the JPL recommendations (Sander et al., 2006). The reactions denoted by ${ }^{*}$ are not included in the standard setup. Sensitivity calculations have shown that these reactions do not significantly affect the amount of $\mathrm{HBr}$ in the UTLS in our model.

\begin{tabular}{llll}
\hline Reactants & & Products & $k(T)\left[\mathrm{cm}^{3} \mathrm{molec}^{-1} \mathrm{~s}^{-1}\right]$ \\
\hline $\mathrm{Br}+\mathrm{CH}_{2} \mathrm{O}$ & $\rightarrow$ & $\mathrm{HBr}+\mathrm{HCO}$ & $1.7 \times 10^{-11} \cdot \exp (-800 / T)$ \\
$\mathrm{Br}+\mathrm{HO}_{2}$ & $\rightarrow$ & $\mathrm{HBr}+\mathrm{O}_{2}$ & $4.8 \times 10^{-12} \cdot \exp (-310 / T)$ \\
${ }^{*} \mathrm{Br}+\mathrm{H}_{2} \mathrm{O}_{2}$ & $\rightarrow$ & $\mathrm{HBr}+\mathrm{HO}_{2}$ & $1.0 \times 10^{-11} \cdot \exp (-3000 / T)$ \\
${ }^{*} \mathrm{BrO}+\mathrm{OH}$ & $\rightarrow$ & $\mathrm{HBr}+\mathrm{O}_{2}$ & $5.1 \times 10^{-13} \cdot \exp (+250 / T)$ \\
$\mathrm{HBr}+\mathrm{OH}$ & $\rightarrow$ & $\mathrm{Br}+\mathrm{H}_{2} \mathrm{O}$ & $5.5 \times 10^{-12} \cdot \exp (+200 / T)$ \\
$\mathrm{HBr}+\mathrm{O}$ & $\rightarrow$ & $\mathrm{Br}+\mathrm{OH}$ & $5.8 \times 10^{-12} \cdot \exp (-1500 / T)$ \\
$\mathrm{HBr}+\mathrm{O}^{1} \mathrm{D}$ & $\rightarrow$ & $\mathrm{Br}+\mathrm{OH}$ & $1.5 \times 10^{-10}$ \\
\hline
\end{tabular}

adsorbed $\mathrm{HBr}$ and releases bromine into gas phase. In contrast, the mixing ratio of $\mathrm{HBr}$ in the UTLS is up to four times higher in the sensitivity calculation without heterogeneous activation. Here, the partitioning of $\mathrm{Br}_{\mathrm{y}}$ is shifted towards $\mathrm{HBr}$ which in turn leads to increased loss of bromine due to scavenging; the resulting profile for $\mathrm{Br}_{\mathrm{y}}$ (Fig. 5) is about 


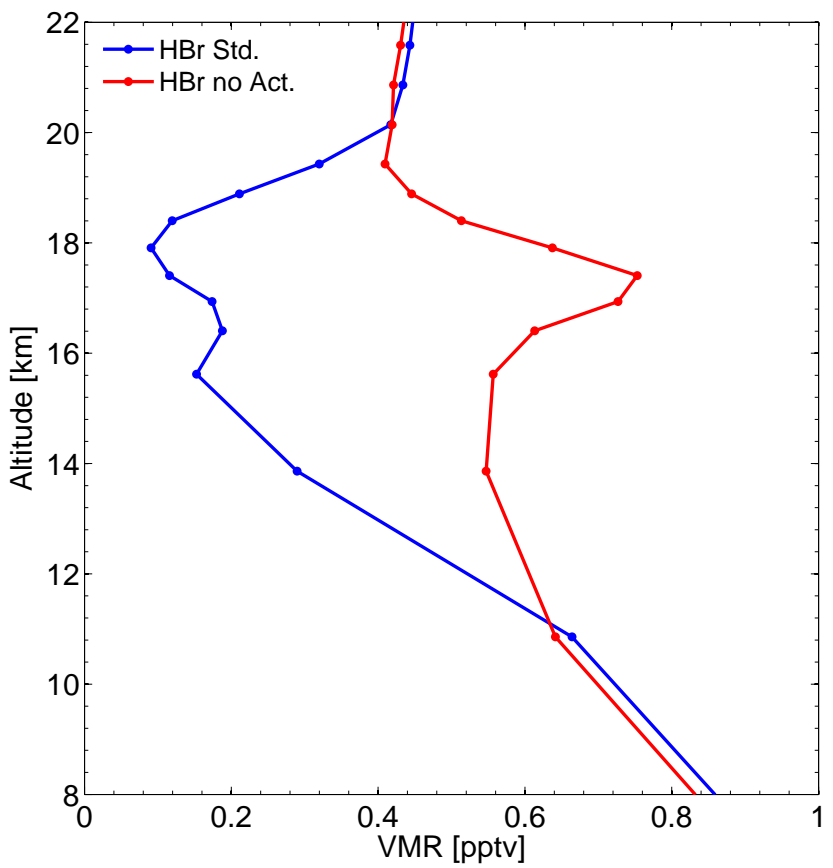

Fig. 7. Tropical profiles of $\mathrm{HBr}$ from the standard full chemistry run (blue) and the sensitivity calculation without heterogeneous activation (red) for 2006.

0.3 pptv lower than in the standard run. Consequently, 4.6 out of $5 \mathrm{pptv}$ of bromine originating from VSLS is able to enter the stratosphere when heterogeneous activation is ignored. An additional sensitivity calculation shows that $96 \%$ of the observed effect can be attributed to heterogeneous reactions on ice particles, in comparison to $3 \%$ and $1 \%$ for heterogeneous reactions on liquid aerosol and NAT particles, respectively. This means that at least in our model ice particles are the most important surface for heterogeneous chemistry in the TTL.

Finally, adsorbed $\mathrm{HBr}$ is not washed out instantaneously but sediments slowly downwards, i.e. it is possible that a significant part evaporates again and eventually reaches the stratosphere. This effect explains the local maximum of $\mathrm{HBr}$ at around $17 \mathrm{~km}$ in the sensitivity run without heterogeneous activation (Fig. 7): repeated sedimentation, evaporation and eventual ascent accumulates the available $\mathrm{HBr}$ in a small vertical range. In fact we likely overestimate the impact of sedimentation assuming a fixed fall velocity based on an average particle radius of $10 \mu \mathrm{m}$. According to Fig. 6 most ice particles are actually smaller (about 0.5 to $2 \mu \mathrm{m}$ ).

\subsection{Development of stratospheric bromine loading over time}

The balance between the processes controlling bromine loading is not static but rather varies significantly with ambient meteorological conditions. To illustrate the connection between the most important variables Figs. 8 and 10 show timeseries of tropical sea surface temperature (SST), detrainment rate $d_{\mathrm{c}}$, brominated short-lived source gases, inorganic brominated product gases and total bromine abundance (i.e. the sum of source and product gases) and the corresponding monthly anomalies from 1990 to 2009 (1989 was discarded to reduce spin-up effects). The values for $d_{\mathrm{c}}$ are averages over the altitude range being most relevant for bromine in the UTLS: from the level of zero clear sky radiative heating at approximately $350 \mathrm{~K}(15.5 \mathrm{~km})$, which marks the transition from large-scale subsidence to large-scale upwelling (e.g., Corti et al., 2005; Sinnhuber and Folkins, 2006), to the cold point at about $380 \mathrm{~K}(17 \mathrm{~km})$ where major parts of tropopause air get effectively dehydrated (e.g., Gettelman et al., 2002a; Fueglistaler et al., 2005). The cold point is also commonly regarded as a likely upper altitude limit for deep convection (e.g., Dessler, 2002). For the tracer timeseries we picked $380 \mathrm{~K}$ for the same reasons: almost all detrainment and dehydration (in the tropics, Fig. 2) occurs below this level so tracers at this altitude are likely to enter the stratosphere with their current mixing ratio at $380 \mathrm{~K}$.

\subsubsection{Idealized setup}

Firstly, Fig. 8 illustrates the relation between sea surface temperature and convective activity in the ECMWF ERAInterim reanalysis: as expected, higher SST lead in general to intensified convection denoted by higher values of $d_{\mathrm{c}}$ (correlation coefficient between the two timeseries is $r=$ 0.53 ) which is in line with real world observations (e.g., Ramanathan and Collins, 1991). Secondly, our calculations show clearly a tight coupling of brominated source gas abundance in the UTLS and detrainment rate $(r=0.69$ for $d_{\mathrm{c}} / \mathrm{TT} 20$ and $\left.d_{\mathrm{c}} / \mathrm{TT} 120\right)$. Quantitatively this affects mostly the short-lived species TT20 $\left(\mathrm{CHBr}_{3}\right)$, for example its mixing ratio at $380 \mathrm{~K}$ increases by about $20 \%$ during the exceptional strong El Niño event 1997/98. For TT120 $\left(\mathrm{CH}_{2} \mathrm{Br}_{2}\right)$ the magnitude of this effect is smaller (e.g., $\sim 6 \%$ during 1997/98) due to its relatively long lifetime.

However, for the product gas $\mathrm{Br}_{\mathrm{y}}$ the situation is more complex. The insoluble variant (not shown here) has no sink in our model but is diluted by detraining air $\left(\left[\mathrm{Br}_{\mathrm{y}}\right]_{\mathrm{c}}=0 \mathrm{pptv}\right)$ leading to a strict anti-correlation to the detrainment rate $(r=-0.70)$. Since the insoluble $\mathrm{Br}_{\mathrm{y}}$ tracer is inert and all brominated VSLS eventually end up as $\mathrm{Br}_{\mathrm{y}}$, the mixing ratio of total bromine converges to a fixed value, in the case of our setup 5 pptv. That means variations in convective activity cannot alter the amount of total bromine once it reaches its equilibrium value of 5 pptv. In contrast, the soluble $\mathrm{Br}_{\mathrm{y}}$ tracer is subject to washout as described in Sect. 2.2 which introduces an additional process that disrupts the strict anticorrelation to $d_{\mathrm{c}}\left(r=-0.40\right.$ for soluble $\left.\mathrm{Br}_{\mathrm{y}} / d_{\mathrm{c}}\right)$. Consequently, total bromine abundance cannot reach equilibrium but varies with the amount of ice or scavenging efficiency. This process is due to our model setup mainly controlled by 
Time series
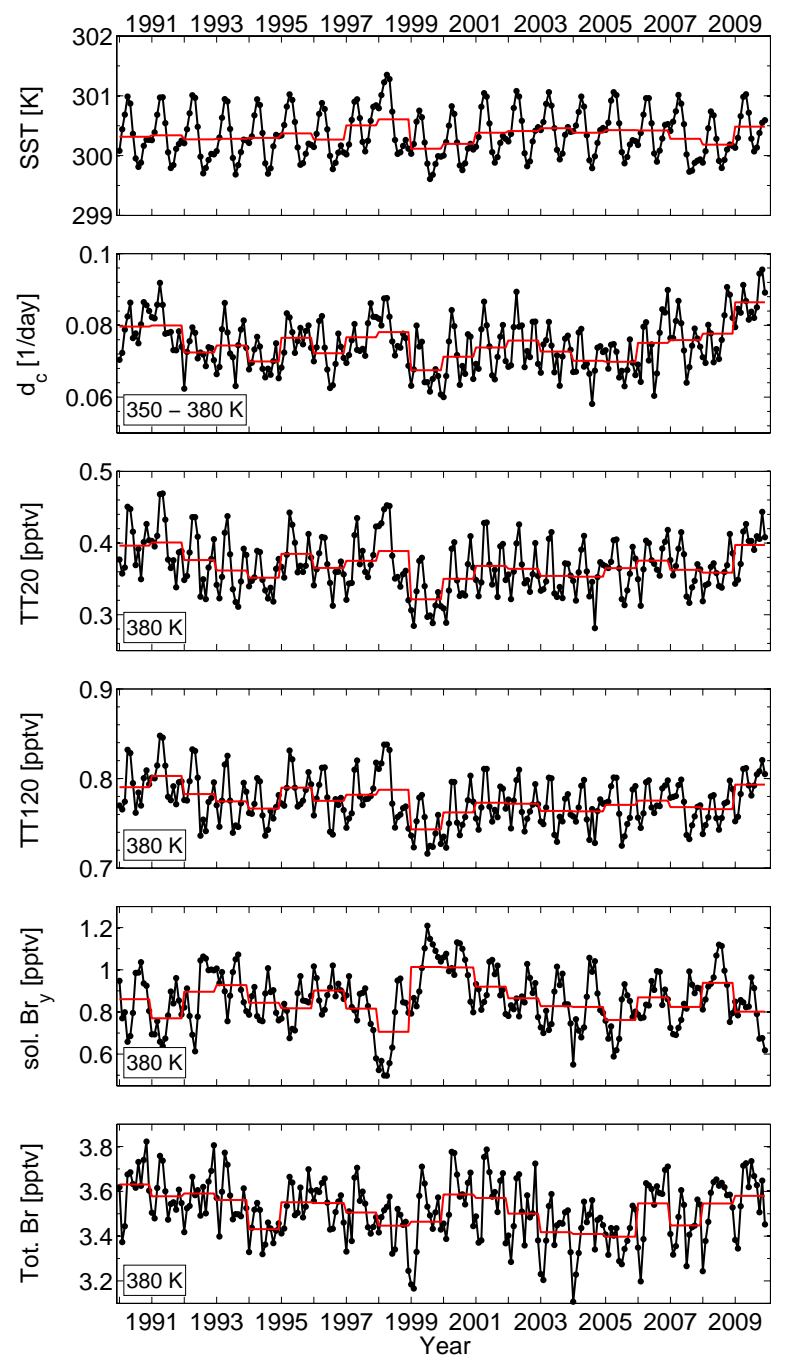

Anomalies
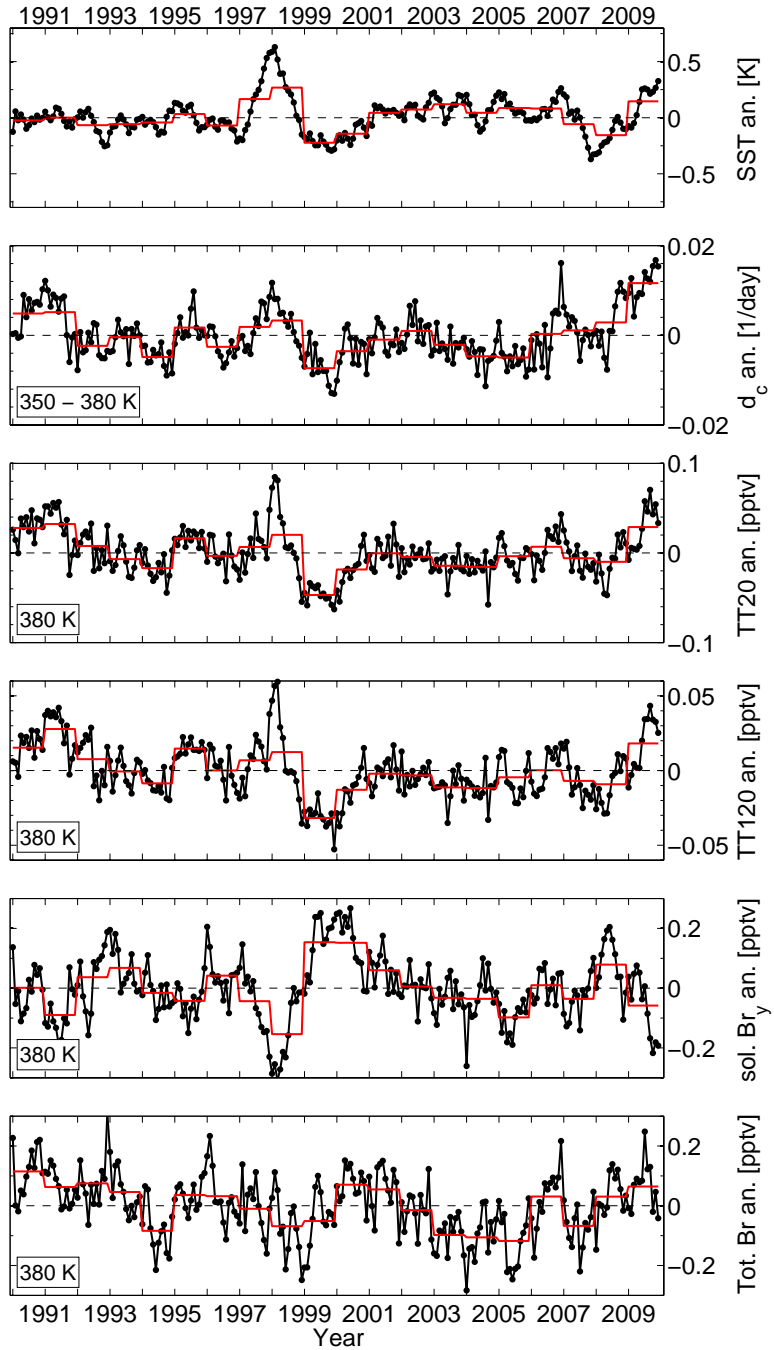

Fig. 8. Timeseries of monthly mean sea surface temperature SST, detrainment rate $d_{\mathrm{c}}$, idealized bromoform tracer TT20, idealized dibromomethane tracer TT120, soluble $\mathrm{Br}_{\mathrm{y}}$ and total bromine (left panels) and the corresponding anomalies (right panels) from 1990 to 2009 averaged over the tropics $\left(20^{\circ} \mathrm{N}\right.$ to $\left.20^{\circ} \mathrm{S}\right)$ at an altitude of approximately $17 \mathrm{~km}(380 \mathrm{~K})$ for the tracers. The values for $d_{\mathrm{c}}$ are an average of the range between the level of zero radiative heating and the cold point (350-380 K). The red lines denote the corresponding yearly average.

relative humidity in the UTLS region, i.e. water vapor content and ambient temperature. Actually there is weak correlation of total bromine with $d_{\mathrm{c}}\left(r=0.44\right.$ for total $\left.\mathrm{Br} / d_{\mathrm{c}}\right)$ which may lead to the conclusion that the additional injection of brominated source gases during strong convection outweighs the decrease due to scavenging, however, there are also short periods where total bromine is anti-correlated to convective activity.

To illustrate the impact of an intense perturbation in convective transport Fig. 9 shows the spatial anomaly distribution of the aforementioned variables for the particular strong El Niño/La Niña seasons 1997/98 and 1999, respectively. For the El Niño season 1997/98 we observe an increase of SST in the equatorial East Pacific and to a lesser extent in the western part of the Indian Ocean. Convective activity gen- erally intensifies in these areas although there is also a decrease of $d_{\mathrm{c}}$ over the maritime continent. This dipole-type structure is also discernible in the distribution of the brominated source gases, TT20 and TT120, but the increase outweighs the loss considering the whole tropics. Interestingly, the mixing ratios of both source gases are actually dropping over the Western Indian Ocean although $d_{\mathrm{c}}$ shows a positive anomaly there. The relative humidity as indicator for scavenging efficiency shows two zonal bands of strong positive anomalies at $20^{\circ} \mathrm{N} / \mathrm{S}$ disrupted by a extensive negative anomaly over the Western Pacific stretching as equatorial band eastward. Mixing ratios of soluble $\mathrm{Br}_{\mathrm{y}}$ are significantly reduced in areas with positive anomalies of relative humidity, exceeding the effect of $\mathrm{Br}_{\mathrm{y}}$ reduction due to dilution by detraining air. The interpretation of the distribution of the 

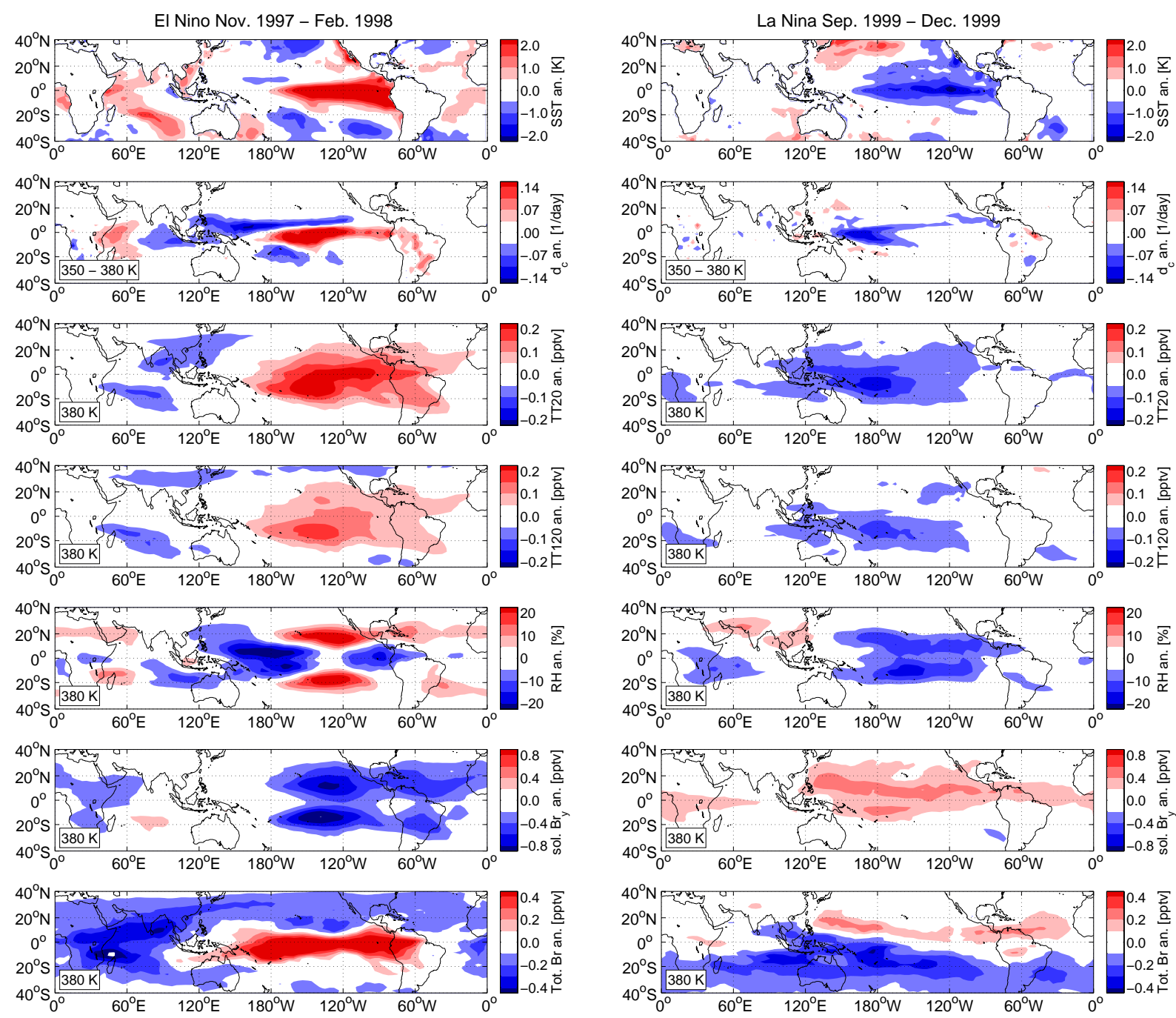

Fig. 9. Averaged anomalies of sea surface temperature SST, detrainment rate $d_{\mathrm{c}}$, idealized bromoform tracer TT20, idealized dibromomethane tracer TT120, relative humidity $\mathrm{RH}$, soluble $\mathrm{Br}_{\mathrm{y}}$ and total bromine. The small boxes denote the corresponding potential temperature level. Left: Averages over El Niño season November 1997 to February 1998. Right: Averages over La Niña season September 1999 to December 1999.

total bromine anomalies is more complex. During El Niño 1997/98, the main features of the distribution, i.e. the strong positive anomaly over the equatorial Pacific next to the negative anomaly over the Indian Ocean, generally correspond to the patterns of TT20 and TT120. However, as explained in the previous paragraph, the amount of total bromine is also directly controlled by the scavenging efficiency, which may outweigh the effect of source gas injection. The positive anomaly of total bromine in the equatorial pacific and the negative anomaly in the Indian Ocean are examples where these those two factors coincide: an increase in source gases is accompanied by an decrease of relative humidity (i.e. scavenging efficiency). However, at $20^{\circ} \mathrm{N} / \mathrm{S}$, this is not the case and total bromine is reduced due to increased washout, although both source gases show a positive anomaly at this latitude (in the Pacific region).
In principle, the La Niña season 1999 shows a similar picture with inverted sign for the detrainment rate and the source gases. However, there are notable differences, the most important is the missing dipole-type structure of the previous El Niño season. This leads to a roughly uniform negative anomaly for the source gases and relative humidity in the $\mathrm{Pa}-$ cific region, whereas soluble $\mathrm{Br}_{\mathrm{y}}$ shows a corresponding positive anomaly. Interestingly, the distribution of total bromine is split up in a small northern positive anomaly and an extensive negative anomaly in the south. The northern anomaly can be explained with the exceptionally low scavenging efficiency in this region which restricts washout of soluble $\mathrm{Br}_{\mathrm{y}}$, however, this explanation is not applicable for the Southern Hemisphere where total bromine is reduced in spite of the low scavenging efficiency. It is possible that the reduced amount of source gases outweighs the impact of scavenging 
in this region or that the negative anomaly is caused by transport of $\mathrm{Br}_{\mathrm{y}}$-depleted air from other areas, for example from India or the northern part of the Maritime Continent, where a positive anomaly of relative humidity exists.

Both examples show the generally tight coupling between convection and the abundance of brominated source gases in the UTLS. However, the amount of bromine that actually advances further into the stratosphere is also strongly dependent on the scavenging efficiency which is in turn determined by ambient temperature and water vapor content (relative humidity) in our idealized framework. Of course in reality convection and relative humidity are not independent but form a complex interaction (e.g., Sherwood and Dessler, 2001; Gettelman et al., 2002b; Jain et al., 2006; Fueglistaler et al., 2009; Tost et al., 2010) which cannot be captured in detail by our idealized approach. Our results suggest that in general the scavenging efficiency tends to be low in areas which show strong convective activity (Figs. 8 and 9) but the limitations of the utilized convective parametrization and water vapor treatment prohibit definite conclusions.

\subsubsection{Full chemistry setup}

The corresponding timeseries for the full chemistry setup are shown in Fig. 10. The picture for the brominated VSLS, bromoform and dibromomethane, is essentially the same as in the idealized setup. Both are correlated to $d_{\mathrm{c}}(r=0.59,0.61$ for $\left.d_{\mathrm{c}} / \mathrm{CHBr}_{3}, d_{\mathrm{c}} / \mathrm{CH}_{2} \mathrm{Br}_{2}\right)$ and bromoform is also more affected quantitatively than dibromomethane.

The pronounced difference to the idealized setup manifests in the mixing ratio of $\mathrm{Br}_{\mathrm{y}}$ /total bromine at $380 \mathrm{~K}$. To remove the influence of the variable long-lived source gases we use for the timeseries of $\mathrm{Br}_{\mathrm{y}}$ /total bromine in Fig. 10 the difference between the reference run without VSLS and the standard full chemistry setup as already described in Sect. 3.2.2. As stated earlier our model suggests that virtually the entire amount of bromine originating from VSLS is able to reach the UTLS region at $380 \mathrm{~K}$. Temporal variations in convective activity and washout efficiency do not have a significant effect; after about two years of spin-up time the mixing ratio of total bromine stays at 5 pptv. In return, $\mathrm{Br}_{\mathrm{y}}$ acts as the insoluble product gas tracer discussed in Sect. 3.3.1: since total bromine has reached the equilibrium value of 5 pptv $\mathrm{Br}_{\mathrm{y}}$ is strictly anti-correlated to convection ( $r=-0.62$ for $d_{\mathrm{c}} / \mathrm{Br}_{\mathrm{y}}$ ) thus balancing out the changing amount of available source gases. Apparently the loss of soluble inorganic bromine species in the tropopause by uptake on ice is negligible in our full chemistry approach as stated in Sect. 3.2.2.

Results from the sensitivity calculation without heterogeneous activation presented in Fig. 11 show that uptake of soluble $\mathrm{Br}_{\mathrm{y}}$ on ice causes an average loss of total bromine of about 0.3 pptv that increases up to 0.5 pptv, for example, during the El Niño season $1997 / 98$ which is roughly $25 \%$ to $30 \%$ of the $\mathrm{Br}_{\mathrm{y}}$ originating from VSLS at $380 \mathrm{~K}$. Interesting to note is the time lag of the total bromine loss during the aforementioned El Niño season: in the idealized setup with instantaneous washout the major loss of total bromine occurs at December 1997 (Fig. 8) in contrast to the full chemistry (sensitivity) run where the minimum is reached around May 1998. Another notable difference to the idealized approach is revealed in the La Niña season at the end of 1999. The idealized run shows a small minimum in total bromine of about 0.1 pptv (Fig. 8) whereas the loss in the full chemistry run is doubled. Apart from these two major events the effect of dehydration on total bromine is generally smaller in the full chemistry sensitivity run than in the idealized setup.

The spatial anomaly patterns of the full chemistry run for the prominent El Niño/La Niña seasons 1997/98 and 1999 are presented in Fig. 12. For $\mathrm{Br}_{\mathrm{y}}$ and total bromine we show the sensitivity calculation without heterogeneous activation to emphasize the effect of ice uptake and sedimentation. For the standard run with heterogeneous activation the effect is much smaller. In addition, to remove the influence of changing long-lived source gases, for $\mathrm{Br}_{\mathrm{y}}$ and total bromine again the difference between the sensitivity run with VSLS and the reference run without VSLS is shown.

For the two VSLS and the relative humidity the spatial patterns and also the magnitude are very similar to the idealized setup (Fig. 9) during both seasons. For inorganic and total bromine there is also a certain resemblance in the patterns but the magnitude differs significantly due to the different treatment of dehydration compared to the idealized setup. In the El Niño season 1997/98 the loss of total bromine is not very distinctive during November 1997 to February 1998 as in the idealized run but occurs rather in May 1998 as shown in Fig. 10. On the other hand the amount of total bromine uniformly decreases during La Niña 1999 in contrast to the partial increase in the idealized framework.

\section{Discussion and conclusions}

In this study we explore the impact of deep convection and dehydration on stratospheric bromine loading due to VSLS over a 21-year period. The isentropic CTM framework we use was already evaluated with observations in a previous study (Aschmann et al., 2009). Utilizing this framework we apply two modeling approaches: a simplified setup with idealized tracers and a basic dehydration mechanism and a state of the art full chemistry scheme based on the original SLIMCAT model. In both modeling approaches we include the two most abundant brominated VSLS, bromoform and dibromomethane, with a uniform detrainment mixing ratio of 1 pptv each.

Our estimated contribution of these short-lived species to the stratospheric bromine loading is 3.4 to $5 \mathrm{pptv}$ for the idealized setup and 4.9 to 5 pptv for the full chemistry setup. These values are in agreement with observations ranging from 3 pptv (Sinnhuber et al., 2005) to 5 and 5.2 pptv 
Time series
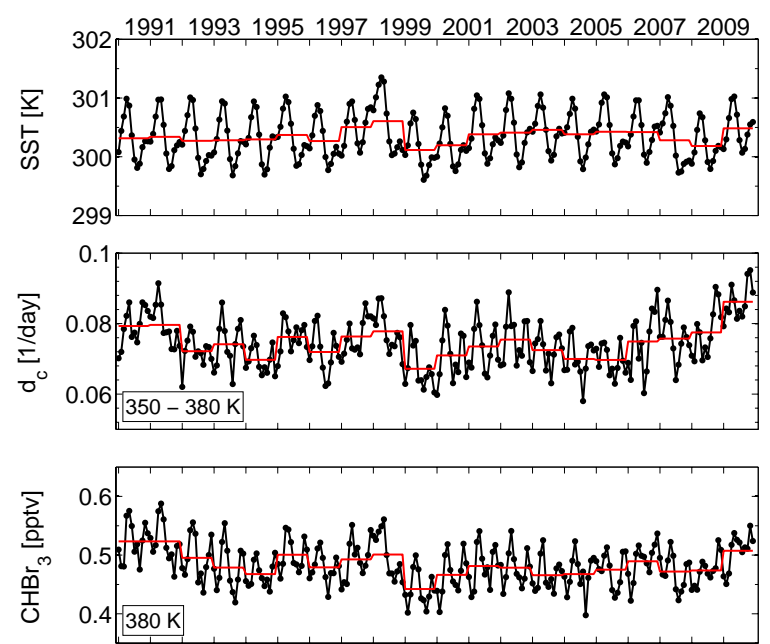

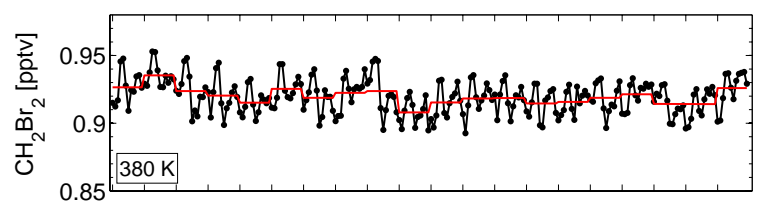
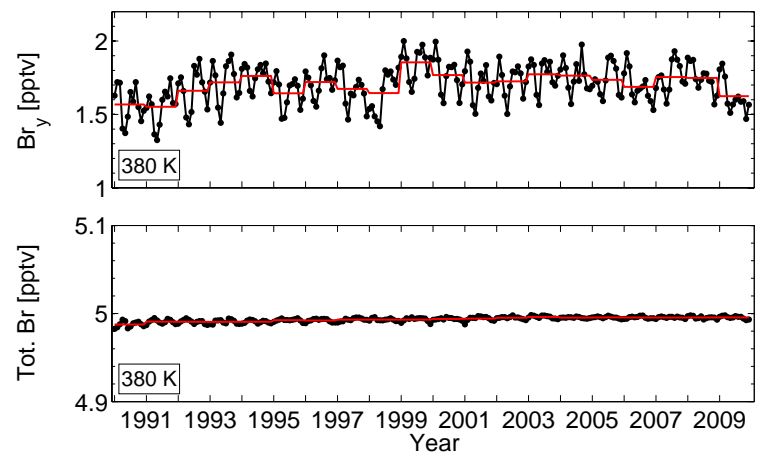

Anomalies

1991199319951997199920012003200520072009
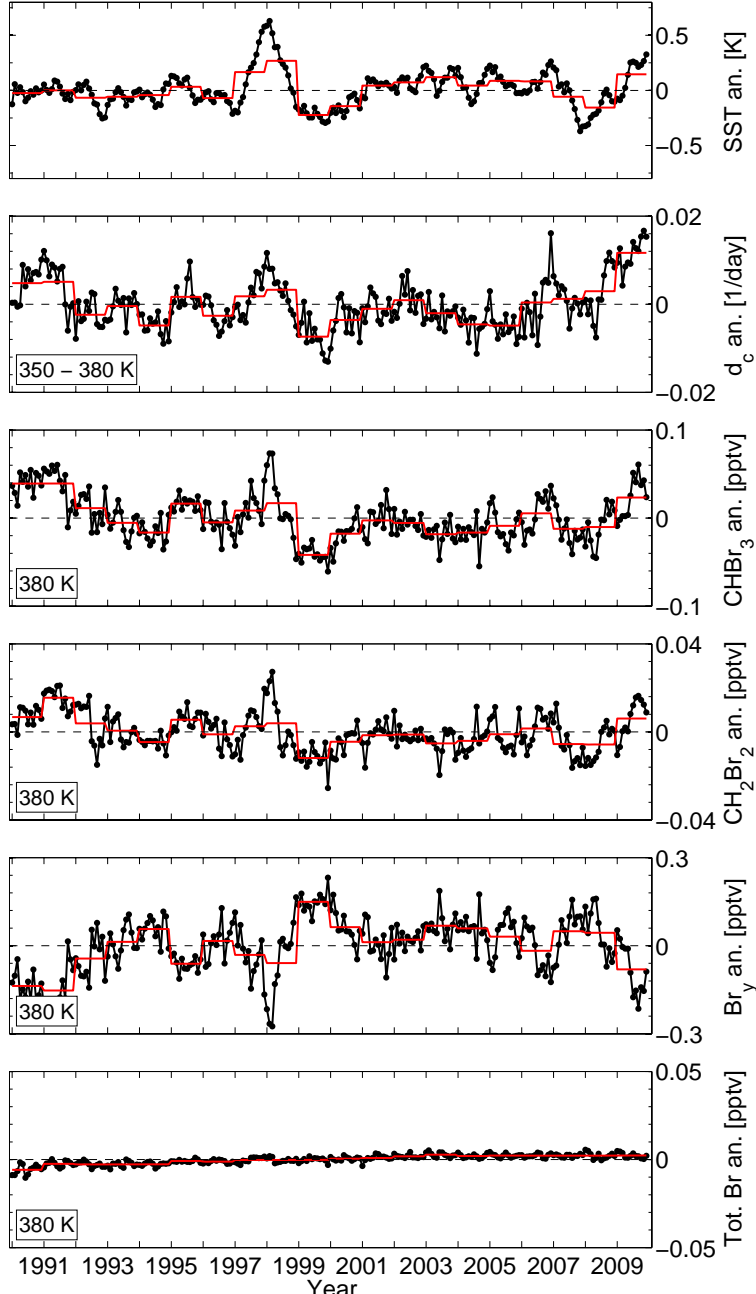

Fig. 10. Timeseries of monthly mean sea surface temperature SST, detrainment rate $d_{\mathrm{c}}$, bromoform $\left(\mathrm{CHBr}_{3}\right)$, dibromomethane $\left(\mathrm{CH}_{2} \mathrm{Br}_{2}\right)$, inorganic brominated product gases $\left(\mathrm{Br}_{\mathrm{y}}\right.$, see Table 1) and total bromine (left panels) and the corresponding anomalies (right panels) from 1990 to 2009 averaged over the tropics $\left(20^{\circ} \mathrm{N}\right.$ to $\left.20^{\circ} \mathrm{S}\right)$ at an altitude of approximately $17 \mathrm{~km}(380 \mathrm{~K})$ for the tracers. The values for $d_{\mathrm{c}}$ are an average of the range between the level of zero radiative heating and the cold point $(350-380 \mathrm{~K})$. The red lines denote the corresponding yearly average. Note: the values for $\mathrm{Br}_{\mathrm{y}}$ and total bromine are actually the difference of the standard full chemistry run and the reference run without VSLS to show the impact of the short-lived substances.
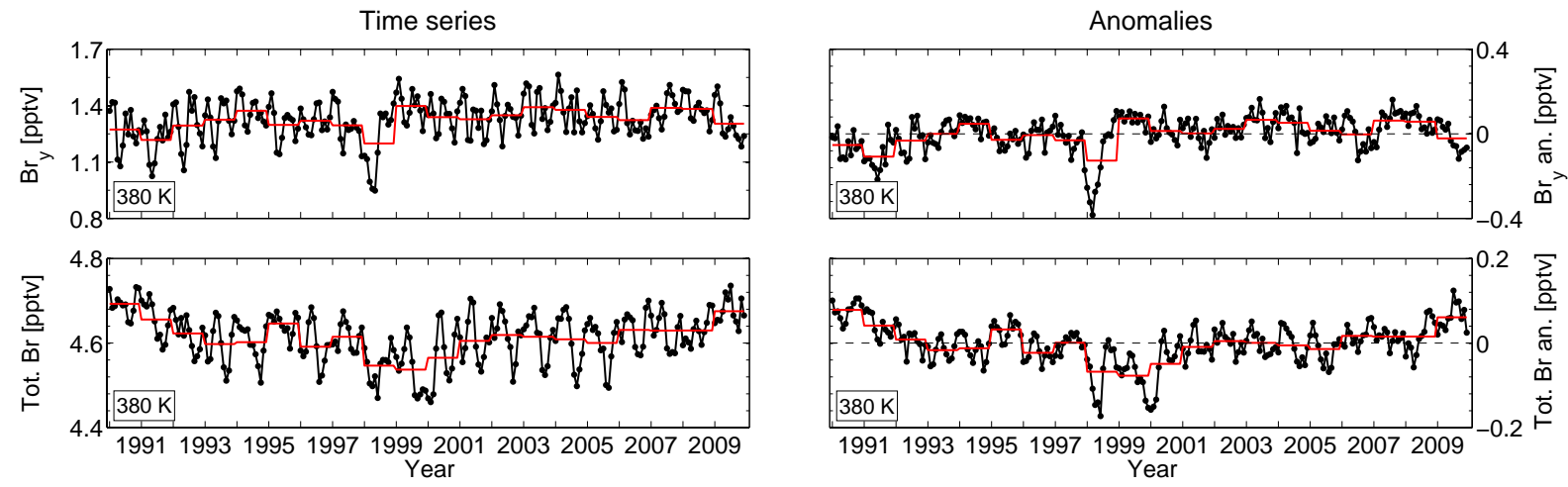

Fig. 11. Timeseries of $\mathrm{Br}_{\mathrm{y}}$, total bromine and the corresponding anomalies as in Fig. 10 but from the sensitivity run without heterogeneous activation. 

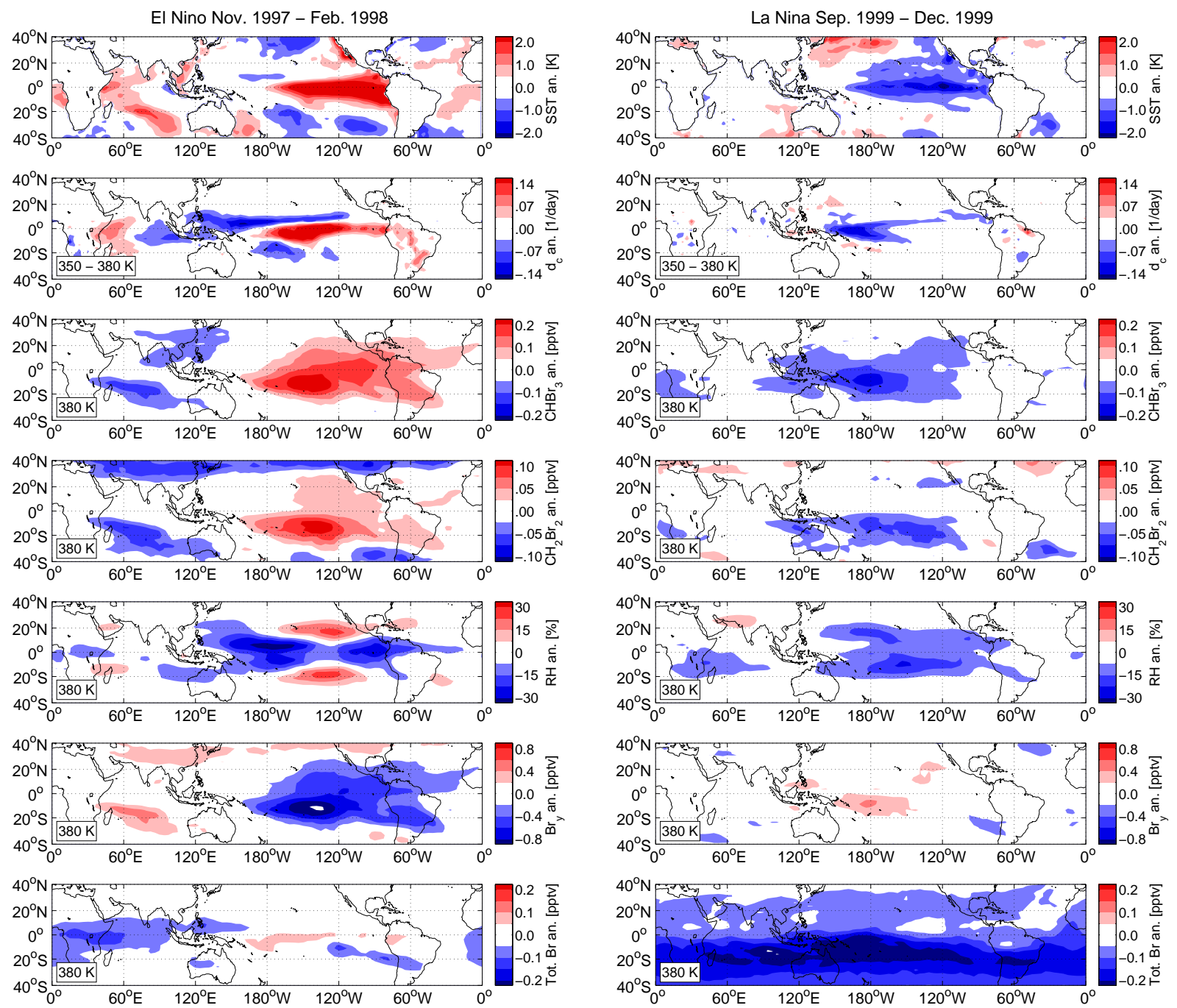

Fig. 12. Averaged anomalies for sea surface temperature, detrainment rate, bromoform, dibromomethane, relative humidity and inorganic and total bromine for the El Niño season 1997/98 (left) and La Niña season 1999 (right) as in Fig. 9 but for the full chemistry setup. Note: the values for $\mathrm{Br}_{\mathrm{y}}$ and total bromine are actually the difference of the full chemistry run without heterogeneous activation and the reference run without VSLS to show the impact of dehydration and short-lived substances (see also Sect. 3.3.2).

(McLinden et al., 2010; Dorf et al., 2008) to 8.4 pptv (Sioris et al., 2006). Compared to other modeling studies our estimation is rather at the higher end. Considering only bromoform the estimated contributions to stratospheric bromine range from 0.8 to 1 pptv (Dvortsov et al., 1999; Nielsen and Douglass, 2001), 0.5 to 3 pptv (Sinnhuber and Folkins, 2006) to 1.6 to 3 pptv (Aschmann et al., 2009). When taking both bromoform and dibromomethane into account recent studies suggest a contribution of 2.4 to 2.8 pptv (Hossaini et al., 2010; Gettelman et al., 2009) up to $4.8 / 5 \mathrm{pptv}$ (Schofield et al., 2011; Liang et al., 2010). Warwick et al. (2006) suggest an even higher value of 6 to 7 pptv but considers five short-lived bromocarbons.

Aside from the uncertainties in the emission strength of short-lived bromocarbons which is not discussed here another key question is the impact of dehydration and scaveng- ing on soluble inorganic bromine species. Depending on the representation of these processes in the model the estimated contribution of VSLS to bromine loading differ significantly.

Table 4 gives an overview of the contribution of bromine VSLS to stratospheric bromine dependent on the applied dehydration mechanism in recent modeling studies together with the results from our work. Hossaini et al. (2010) assume a constant washout lifetime of 10 days for $\mathrm{Br}_{\mathrm{y}}$, resulting in a loss of $60 \%$ of bromine originated from VSLS. In the approach of Schofield et al. (2011), 85\% of $\mathrm{Br}_{\mathrm{y}}$ is removed at the cold point, resulting in a loss of $38 \%$ of bromine contributed by VSLS. Our idealized setup, which uses a comparable simple approach for dehydration, suggests a loss of $32 \%$ of bromine produced by VSLS. In contrast to the simple dehydration mechanisms, Liang et al. (2010) use a detailed wet and dry deposition scheme to calculate the loss of $\mathrm{Br}_{\mathrm{y}}$. 
Table 4. Overview of the contribution of VSLS to stratospheric bromine loading (SBL) and the impact of dehydration in different modeling studies. The columns give the average tropical mixing ratio of available bromine in the form of VSLS and the stratospheric bromine loading due to VSLS. The ratio of both values represents the loss of bromine due to dehydration.

\begin{tabular}{lrrr}
\hline Study & $\begin{array}{r}\text { Available } \\
\text { VSLS [pptv] }\end{array}$ & $\begin{array}{r}\text { SBL due } \\
\text { to VSLS [pptv] }\end{array}$ & $\begin{array}{r}\text { Loss due } \\
\text { to dehydration }\end{array}$ \\
\hline Hossaini et al. (2010) & 6 & 2.4 & $60 \%$ \\
Schofield et al. (2011) & 7.7 & 4.8 & $38 \%$ \\
Liang et al. (2010) & 7 & 5 & $30 \%$ \\
Idealized setup & 5 & 3.4 & $32 \%$ \\
Full chemistry & 5 & $>4.9$ & $<2 \%$ \\
Full chemistry & & & 8.6 \\
(no het. activ.) & 5 & & \\
\hline
\end{tabular}

They state that $30 \%$ of $\mathrm{Br}_{\mathrm{y}}$ produced by VSLS is removed by wet scavenging, however, $85 \%$ of this wet removal occurs below $500 \mathrm{hPa}(5-6 \mathrm{~km})$. Consequently, about $5 \%$ of $\mathrm{Br}_{\mathrm{y}}$ produced by VSLS is scavenged above $500 \mathrm{hPa}$. These findings are consistent with the results of our full chemistry setup, if we ignore heterogeneous activation (about $8 \%$ loss). Taking into account the heterogeneous chemistry lowers the loss of $\mathrm{Br}_{\mathrm{y}}$ below $2 \%$ thus rendering the influence of dehydration in the UTLS on bromine loading insignificant.

Our 21-year timeseries show the correlation of sea surface temperature to convective activity and in turn to the amount of VSLS and $\mathrm{Br}_{\mathrm{y}}$ at the tropopause (Sect. 3.3). However, we find that the impact of deep convection on total bromine in our model depends on the treatment of dehydration and wet scavenging. In the full chemistry setup total bromine is practically insensitive to moderate changes in the convective detrainment rate (Fig. 10). The more "aggressive" approach in the idealized setup suggests that on average more bromine reaches the stratosphere in total during strong convective events, as illustrated in Fig. 9 for the exceptional El Niño event $1997 / 98$, but that is not necessarily the case in local areas where washout can be the dominating process. In general, the phases of the ENSO cycle offer a good opportunity to study the impact of varying convection and dehydration on stratospheric bromine under extreme conditions (Fig. 9, 12).

Our conclusions from this study can be summarized as follows:

1. Uptake and sedimentation of $\mathrm{HBr}$ on ice seems not to be a very efficient loss process of inorganic bromine in the UTLS (less than $2 \%$ of $\mathrm{Br}_{\mathrm{y}}$ originating from VSLS is lost). The modeled fraction of $\mathrm{HBr}$ to $\mathrm{Br}_{\mathrm{y}}$ is small in the tropical UTLS $(\sim 5 \%)$.

2. The relatively small amount of adsorbed $\mathrm{HBr}$ on ice (6$8 \%$ of $\mathrm{Br}_{\mathrm{y}}$ originating from VSLS) is almost entirely released back into gas phase by heterogeneous activation.
3. Convective transport shows large inter-annual variation in relation to SST variations. In turn, the abundance of VSLS reaching the stratosphere is highly correlated to convective activity. However, the impact on total stratospheric bromine depends on the implementation of the dehydration process. Total bromine in the full chemistry scheme is nearly insensitive to dehydration whereas the idealized setup generally predicts an increased amount of total bromine in the UTLS during events of strong convective activity.

4. The fact that the detailed chemistry scheme indicates very little removal of $\mathrm{Br}_{\mathrm{y}}$ by falling ice means that almost all of the bromine from VSLS in areas of deep convection ultimately enters the stratosphere, largely independent of the details of the transport pathways. This important result should be confirmed by further refined studies of ice particle formation, sedimentation and uptake of brominated species (like, e.g., Grosvenor et al., 2007; Chaboureau et al., 2007; Read et al., 2008).

5. If removal of $\mathrm{Br}_{\mathrm{y}}$ by uptake and sedimentation is indeed not very efficient then the flux of VSLS bromine into the stratosphere will be largely controlled by the distribution of VSLS in the troposphere and the pathways by which VSLS enters deep convective uplift.

Acknowledgements. J. A. acknowledges financial support by the University of Bremen through project VSLS (ZF 01/127/07). Parts of this work were supported by the EU projects SCOUT-O3 and SHIVA (226224-FP7-ENV-2008-1) and the DFG research unit SHARP. ERA-Interim data were provided through the ECMWF special project DECDIO. We thank M. Ammann for helpful comments regarding the $\mathrm{HBr}$ uptake on ice and $\mathrm{N}$. Wieters for support in integrating the chemistry scheme into the CTM framework. We thank R. Schofield and the anonymous reviewer for their helpful comments.

Edited by: M. Dameris

\section{References}

Aschmann, J., Sinnhuber, B.-M., Atlas, E. L., and Schauffler, S. M.: Modeling the transport of very short-lived substances into the tropical upper troposphere and lower stratosphere, Atmos. Chem. Phys., 9, 9237-9247, doi:10.5194/acp-9-9237-2009, 2009.

Barsugli, J. J. and Sardeshmukh, P. D.: Global atmospheric sensitivity to tropical SST anomalies throughout the Indo-Pacific basin, J. Climate, 15, 3427-3442, 2002.

Böhm, H. P.: A general equation for the terminal fall speed of solid hydrometeors, J. Atmos. Sci., 46, 2419-2427, 1989.

Butler, J. H., King, D. B., Lobert, J. M., Montzka, S. A., YvonLewis, S. A., Hall, B. D., Warwick, N. J., Mondeel, D. J., Aydin, M., and Elkins, J. W.: Oceanic distributions and emissions of short-lived halocarbons, Global Biogeochem. Cy., 21, GB1023, doi:10.1029/2006GB002732, 2007. 
Carpenter, L. J. and Liss, P. S.: On temperate sources of bromoform and other reactive organic bromine gases, J. Geophys. Res.Atmos., 105, 20539-20547, 2000.

Carslaw, K. S., Clegg, S. L., and Brimblecombe, P.: A thermodynamic model of the system $\mathrm{HCl}-\mathrm{HNO}_{3}-\mathrm{H}_{2} \mathrm{SO}_{4}-\mathrm{H}_{2} \mathrm{O}$, including solubilities of $\mathrm{HBr}$, from less-than-200 to $328 \mathrm{~K}$, J. Phys. Chem.US, 99, 11557-11574, 1995a.

Carslaw, K. S., Luo, B. P., and Peter, T.: An analytic-expression for the composition of aqueous $\mathrm{HNO}_{3}-\mathrm{H}_{2} \mathrm{SO}_{4}$ stratospheric aerosols including gas-phase removal of $\mathrm{HNO}_{3}$, Geophys. Res. Lett., 22, 1877-1880, 1995b.

Chaboureau, J.-P., Cammas, J.-P., Duron, J., Mascart, P. J., Sitnikov, N. M., and Voessing, H.-J.: A numerical study of tropical cross-tropopause transport by convective overshoots, Atmos. Chem. Phys., 7, 1731-1740, doi:10.5194/acp-7-1731-2007, 2007.

Chiang, J. C. H. and Sobel, A. H.: Tropical tropospheric temperature variations caused by ENSO and their influence on the remote tropical climate, J. Climate, 15, 2616-2631, 2002.

Chipperfield, M. P.: Multiannual simulations with a threedimensional chemical transport model, J. Geophys. Res.-Atmos., 104, 1781-1805, 1999.

Corti, T., Luo, B. P., Peter, T., Vomel, H., and Fu, Q.: Mean radiative energy balance and vertical mass fluxes in the equatorial upper troposphere and lower stratosphere, Geophys. Res. Lett., 32, L06802, doi:10.1029/2004GL021889, 2005.

Crowley, J. N., Ammann, M., Cox, R. A., Hynes, R. G., Jenkin, M. E., Mellouki, A., Rossi, M. J., Troe, J., and Wallington, T. J.: Evaluated kinetic and photochemical data for atmospheric chemistry: Volume $\mathrm{V}$ - heterogeneous reactions on solid substrates, Atmos. Chem. Phys., 10, 9059-9223, doi:10.5194/acp-10-9059-2010, 2010.

Daniel, J. S. and Velders, G. J. M.: A Focus on Information and Options for Policymakers, Scientific assessment of ozone depletion: 2010, Global Ozone Research and Monitoring Project. Report No. 52, Chapter 5, World Meteorological Organization, Geneva, Switzerland, 2010.

Dessler, A. E.: The effect of deep, tropical convection on the tropical tropopause layer, J. Geophys. Res.-Atmos., 107, 4033, doi:10.1029/2001JD000511, 2002.

Dessler, A. E. and Sherwood, S. C.: Effect of convection on the summertime extratropical lower stratosphere, J. Geophys. Res.Atmos., 109, D23301, doi:10.1029/2004JD005209, 2004.

Dorf, M., Butz, A., Camy-Peyret, C., Chipperfield, M. P., Kritten, L., and Pfeilsticker, K.: Bromine in the tropical troposphere and stratosphere as derived from balloon-borne $\mathrm{BrO}$ observations, Atmos. Chem. Phys., 8, 7265-7271, doi:10.5194/acp-87265-2008, 2008.

Dvortsov, V. L., Geller, M. A., Solomon, S., Schauffler, S. M., Atlas, E. L., and Blake, D. R.: Rethinking reactive halogen budgets in the midlatitude lower stratosphere, Geophys. Res. Lett., 26, 1699-1702, 1999.

Fueglistaler, S., Bonazzola, M., Haynes, P. H., and Peter, T.: Stratospheric water vapor predicted from the Lagrangian temperature history of air entering the stratosphere in the tropics, J. Geophys. Res.-Atmos., 110, D08107, doi:10.1029/2004JD005516, 2005.

Fueglistaler, S., Dessler, A. E., Dunkerton, T. J., Folkins, I., Fu, Q., and Mote, P. W.: Tropical Tropopause Layer, Rev. Geophys., 47, doi:10.1029/2008RG000267, 2009.
Gettelman, A., Randel, W. J., Wu, F., and Massie, S. T.: Transport of water vapor in the tropical tropopause layer, Geophys. Res. Lett., 29, 1009, doi:10.1029/2001GL013818, 2002a.

Gettelman, A., Salby, M. L., and Sassi, F.: Distribution and influence of convection in the tropical tropopause region, J. Geophys. Res.-Atmos., 107, 4080, doi:10.1029/2001JD001048, 2002b.

Gettelman, A., Lauritzen, P. H., Park, M., and Kay, J. E.: Processes regulating short-lived species in the tropical tropopause layer, J. Geophys. Res.-Atmos., 114, 4080, doi:10.1029/2009JD011785, 2009.

Grooß, J.-U. and Russell III, J. M.: Technical note: A stratospheric climatology for $\mathrm{O}_{3}, \mathrm{H}_{2} \mathrm{O}, \mathrm{CH}_{4}, \mathrm{NO}_{\mathrm{x}}, \mathrm{HCl}$ and $\mathrm{HF}$ derived from HALOE measurements, Atmos. Chem. Phys., 5, 2797-2807, doi:10.5194/acp-5-2797-2005, 2005.

Grosvenor, D. P., Choularton, T. W., Coe, H., and Held, G.: A study of the effect of overshooting deep convection on the water content of the TTL and lower stratosphere from Cloud Resolving Model simulations, Atmos. Chem. Phys., 7, 4977-5002, doi:10.5194/acp-7-4977-2007, 2007.

Guilyardi, E., Braconnot, P., Jin, F.-F., Kim, S. T., Kolasinski, M., Li, T., and Musat, I.: Atmosphere Feedbacks during ENSO in a Coupled GCM with a Modified Atmospheric Convection Scheme, J. Climate, 22, 5698-5718, doi:10.1175/2009JCLI2815.1, 2009.

Hanisco, T. F., Moyer, E. J., Weinstock, E. M., St. Clair, J. M., Sayres, D. S., Smith, J. B., Lockwood, R., Anderson, J. G., Dessler, A. E., Keutsch, F. N., Spackman, J. R., Read, W. G., and Bui, T. P.: Observations of deep convective influence on stratospheric water vapor and its isotopic composition, Geophys. Res. Lett., 34, L04814, doi:10.1029/2006GL027899, 2007.

Hanson, D. and Mauersberger, K.: Laboratory studies of the nitricacid trihydrate - implications for the south polar stratosphere, Geophys. Res. Lett., 15, 855-858, 1988.

Holton, J. R. and Gettelman, A.: Horizontal transport and the dehydration of the stratosphere, Geophys. Res. Lett., 28, 2799-2802, 2001.

Hossaini, R., Chipperfield, M. P., Monge-Sanz, B. M., Richards, N. A. D., Atlas, E., and Blake, D. R.: Bromoform and dibromomethane in the tropics: a 3-D model study of chemistry and transport, Atmos. Chem. Phys., 10, 719-735, doi:10.5194/acp-10-719-2010, 2010.

Jain, A. R., Das, S. S., Mandal, T. K., and Mitra, A. P.: Observations of extremely low tropopause temperature over the Indian tropical region during monsoon and postmonsoon months: possible implications, J. Geophys. Res.-Atmos., 111, D07106, doi:10.1029/2005JD005850, 2006.

Jiang, J. H., Su, H., Pawson, S., Liu, H.-C., Read, W. G., Waters, J. W., Santee, M. L., Wu, D. L., Schwartz, M. J., Livesey, N. J., Lambert, A., Fuller, R. A., and Lee, J. N.: Five year (2004-2009) observations of upper tropospheric water vapor and cloud ice from MLS and comparisons with GEOS-5 analyses, J. Geophys. Res.-Atmos., 115, D15103, doi:10.1029/2009JD013256, 2010.

Kerkweg, A., Jöckel, P., Warwick, N., Gebhardt, S., Brenninkmeijer, C. A. M., and Lelieveld, J.: Consistent simulation of bromine chemistry from the marine boundary layer to the stratosphere - Part 2: Bromocarbons, Atmos. Chem. Phys., 8, 5919-5939, doi:10.5194/acp-8-5919-2008, 2008.

Lary, D. J.: Gas phase atmospheric bromine photochemistry, J. Geo- 
phys. Res.-Atmos., 101, 1505-1516, 1996.

Lary, D. J., Chipperfield, M. P., Toumi, R., and Lenton, T.: Heterogeneous atmospheric bromine chemistry, J. Geophys. Res.Atmos., 101, 1489-1504, 1996.

Montzka, S. A. and Reimann, S.: Ozone-Depleting Substances (ODSs) and Related Chemicals, Scientific assessment of ozone depletion: 2010, Global Ozone Research and Monitoring Project. Report No. 52, Chapter 1, World Meteorological Organization, Geneva, Switzerland, 2010.

Liang, Q., Stolarski, R. S., Kawa, S. R., Nielsen, J. E., Douglass, A. R., Rodriguez, J. M., Blake, D. R., Atlas, E. L., and Ott, L. E.: Finding the missing stratospheric Bry: a global modeling study of $\mathrm{CHBr}_{3}$ and $\mathrm{CH}_{2} \mathrm{Br}_{2}$, Atmos. Chem. Phys., 10, 2269-2286, doi:10.5194/acp-10-2269-2010, 2010.

Lowe, D. and MacKenzie, A. R.: Polar stratospheric cloud microphysics and chemistry, J. Atmos. Sol.-Terr. Phy., 70, 13-40, doi:10.1016/j.jastp.2007.09.011, 2008.

McLinden, C. A., Haley, C. S., Lloyd, N. D., Hendrick, F., Rozanov, A., Sinnhuber, B.-M., Goutail, F., Degenstein, D. A., Llewellyn, E. J., Sioris, C. E., Van Rozendael, M., Pommereau, J. P., Lotz, W., and Burrows, J. P.: Odin/OSIRIS observations of stratospheric BrO: Retrieval methodology, climatology, and inferred $\mathrm{Br}_{\mathrm{y}}$, J. Geophys. Res.-Atmos., 115, D15308, doi:10.1029/2009JD012488, 2010.

Mote, P. W., Rosenlof, K. H., Holton, J. R., Harwood, R. S., and Waters, J. W.: Seasonal-variations of water-vapor in the tropical lower stratosphere, Geophys. Res. Lett., 22, 1093-1096, 1995.

Nielsen, J. E. and Douglass, A. R.: Simulation of bromoform's contribution to stratospheric bromine, J. Geophys. Res.-Atmos., 106, 8089-8100, 2001.

Quack, B. and Wallace, D. W. R.: Air-sea flux of bromoform: Controls, rates, and implications, Global Biogeochem. Cy., 17, 1023, doi:10.1029/2002GB001890, 2003.

Ramanathan, V. and Collins, W.: Thermodynamic regulation of ocean warming by cirrus clouds deduced from observations of the 1987 El-Niño, Nature, 351, 27-32, 1991.

Read, W. G., Schwartz, M. J., Lambert, A., Su, H., Livesey, N. J., Daffer, W. H., and Boone, C. D.: The roles of convection, extratropical mixing, and in-situ freeze-drying in the Tropical Tropopause Layer, Atmos. Chem. Phys., 8, 6051-6067, doi:10.5194/acp-8-6051-2008, 2008.

Rodriguez, J. M., Ko, M. K. W., Sze, N. D., Pierce, S. D., Anderson, J. G., Fahey, D. W., Kelly, K., Farmer, C. B., Toon, G. C., Coffey, M. T., Heidt, L. E., Mankin, W. G., Chan, K. R., Starr, W. L., Vedder, J. F., and McCormick, M. P.: Nitrogen and chlorine species in the spring antarctic stratosphere - comparison of models with airborne antarctic ozone experiment observations, J. Geophys. Res.-Atmos., 94, 16683-16703, 1989.

Romps, D. M. and Kuang, Z.: Do undiluted convective plumes exist in the upper tropical troposphere?, J. Atmos. Sci., 67, 468-484, doi:10.1175/2009JAS3184.1, 2010.

Sander, S. P., Friedl, R. R., Golden, D. M., Kurylo, M. J., Moortgat, G. K., Keller-Rudek, H., Wine, P. H., Ravishankara, A. R., Kolb, C. E., Molina, M. J., Finlayson-Pitts, B. J., Huie, R. E., and Orkin, V. L.: Chemical kinetics and photochemical data for use in atmospheric studies: Evaluation number 15, JPL Publ. 06-2, Jet Propul. Lab., Pasadena, CA, 2006.
Schofield, R., Fueglistaler, S., Wohltmann, I., and Rex, M.: Sensitivity of stratospheric $\mathrm{Br}_{\mathrm{y}}$ to uncertainties in very short lived substance emissions and atmospheric transport, Atmos. Chem. Phys., 11, 1379-1392, doi:10.5194/acp-11-1379-2011, 2011.

Sherwood, S. C. and Dessler, A. E.: A model for transport across the tropical tropopause, J. Atmos. Sci., 58, 765-779, 2001.

Sinnhuber, B.-M. and Folkins, I.: Estimating the contribution of bromoform to stratospheric bromine and its relation to dehydration in the tropical tropopause layer, Atmos. Chem. Phys., 6, 4755-4761, doi:10.5194/acp-6-4755-2006, 2006.

Sinnhuber, B. M., Arlander, D. W., Bovensmann, H., Burrows, J. P., Chipperfield, M. P., Enell, C. F., Friess, U., Hendrick, F., Johnston, P. V., Jones, R. L., Kreher, K., Mohamed-Tahrin, N., Muller, R., Pfeilsticker, K., Platt, U., Pommereau, J.-P., Pundt, I., Richter, A., South, A. M., Tornkvist, K. K., Van Roozendael, M., Wagner, T., and Wittrock, F.: Comparison of measurements and model calculations of stratospheric bromine monoxide, J. Geophys. Res.-Atmos., 107, 4398, doi:10.1029/2001JD000940, 2002.

Sinnhuber, B.-M., Rozanov, A., Sheode, N., Afe, O. T., Richter, A., Sinnhuber, M., Wittrock, F., Burrows, J. P., Stiller, G. P., von Clarmann, T., and Linden, A.: Global observations of stratospheric bromine monoxide from SCIAMACHY, Geophys. Res. Lett., 32, L20810, doi:10.1029/2005GL023839, 2005.

Sinnhuber, M., Burrows, J. P., Chipperfield, M. P., Jackman, C. H., Kallenrode, M. B., Künzi, K. F., and Quack, M.: A model study of the impact of magnetic field structure on atmospheric composition during solar proton events, Geophys. Res. Lett., 30, 1818, doi:10.1029/2003GL017265, 2003.

Sioris, C. E., Kovalenko, L. J., McLinden, C. A., Salawitch, R. J., Van Roozendael, M., Goutail, F., Dorf, M., Pfeilsticker, K., Chance, K., von Savigny, C., Liu, X., Kurosu, T. P., Pommereau, J.-P., Boesch, H., and Frerick, J.: Latitudinal and vertical distribution of bromine monoxide in the lower stratosphere from Scanning Imaging Absorption Spectrometer for Atmospheric Chartography limb scattering measurements, J. Geophys. Res.Atmos., 111, D14301, doi:10.1029/2005JD006479, 2006.

Solomon, S.: Stratospheric ozone depletion: a review of concepts and history, Rev. Geophys., 37, 275-316, 1999.

Stiller, G. P., von Clarmann, T., Höpfner, M., Glatthor, N., Grabowski, U., Kellmann, S., Kleinert, A., Linden, A., Milz, M., Reddmann, T., Steck, T., Fischer, H., Funke, B., LópezPuertas, M., and Engel, A.: Global distribution of mean age of stratospheric air from MIPAS SF 6 measurements, Atmos. Chem. Phys., 8, 677-695, doi:10.5194/acp-8-677-2008, 2008.

Tost, H., Lawrence, M. G., Brühl, C., Jöckel, P., The GABRIEL Team, and The SCOUT-O3-DARWIN/ACTIVE Team: Uncertainties in atmospheric chemistry modelling due to convection parameterisations and subsequent scavenging, Atmos. Chem. Phys., 10, 1931-1951, doi:10.5194/acp-10-1931-2010, 2010.

Warwick, N. J., Pyle, J. A., Carver, G. D., Yang, X., Savage, N. H., O'Connor, F. M., and Cox, R. A.: Global modeling of biogenic bromocarbons, J. Geophys. Res.-Atmos., 111, D24305, doi:10.1029/2006JD007264, 2006.

Winkler, H., Sinnhuber, M., Notholt, J., Kallenrode, M.-B., Steinhilber, F., Vogt, J., Zieger, B., Glassmeier, K.-H., and Stadelmann, A.: Modeling impacts of geomagnetic field variations on middle atmospheric ozone responses to solar proton events on long timescales, J. Geophys. Res.-Atmos., 113, D02302, 
doi:10.1029/2007JD008574, 2008.

Yang, X., Cox, R. A., Warwick, N. J., Pyle, J. A., Carver, G. D., O'Connor, F. M., and Savage, N. H.: Tropospheric bromine chemistry and its impacts on ozone: a model study, J. Geophys. Res.-Atmos., 110, D23311, doi:10.1029/2005JD006244, 2005.
Yokouchi, Y., Hasebe, F., Fujiwara, M., Takashima, H., Shiotani, M., Nishi, N., Kanaya, Y., Hashimoto, S., Fraser, P., Toom-Sauntry, D., Mukai, H., Nojiri, Y.: Correlations and emission ratios among bromoform, dibromochloromethane, and dibromomethane in the atmosphere, J. Geophys. Res.-Atmos., 110, D23309, doi:10.1029/2005JD006303, 2005. 